\title{
Ice-free conditions in Novaya Zemlya 35 000-30 000 cal years B.P., as indicated by radiocarbon ages and amino acid racemization evidence from marine molluscs
}

\author{
Jan Mangerud', Darrell Kaufman², Jesper Hansen ${ }^{3}$ \& John Inge Svendsen ${ }^{1}$ \\ 1 Department of Earth Science and Bjerknes Centre for Climate Research, University of Bergen, Allégt. 41, NO-5007 Bergen, Norway \\ 2 Department of Geology, Northern Arizona University, Flagstaff, AZ 86011, USA \\ 3 Department of Natural Science, Tromsø University Museum, NO-9037 Tromsø, Norway
}

\section{Keywords}

amino acid racemization; Barents Sea ice

sheet; Eurasian ice sheet; Last Glacial

Maximum; marine molluscs.

\section{Correspondence}

Jan Mangerud, Department of Earth

Science, University of Bergen, Allégt. 41, NO-5007 Bergen, Norway.

E-mail: Jan.Mangerud@geo.uib.no

doi:10.1111/j.1751-8369.2008.00064.x

\begin{abstract}
Novaya Zemlya was covered by the eastern part of the Barents-Kara ice sheet during the glacial maximum of marine isotope stage 2 (MIS 2). We obtained ${ }^{14} \mathrm{C}$ ages on 37 samples of mollusc shells from various sites on the islands. Most samples yielded ages in the range of $48-26{ }^{14} \mathrm{C} \mathrm{Ky}$. Such old samples are sensitive to contamination by young ${ }^{14} \mathrm{C}$, and therefore their reliability was assessed using replicate analyses and amino acid geochronology. The extent of aspartic acid racemization (Asp D/L) indicates that many of the ${ }^{14} \mathrm{C}$ ages are correct, whereas some are minimum ages only. The results indicate that a substantial part of Novaya Zemlya was ice-free about $35-27{ }^{14} \mathrm{C}$ Kya, and probably even earlier. Corresponding shorelines up to $>140 \mathrm{~m}$ a.s.l. indicate a large Barents-Kara ice sheet during early MIS 3 . These results are consistent with findings from Svalbard and northern Russia: in both places a large MIS 4/3 Barents-Kara ice sheet is postulated to have retreated about 50 Kya, followed by an ice-free interstadial that lasted until up to ca. 25 Kya. The duration of the MIS 2 glaciation in Novaya Zemlya was calculated by applying the $\mathrm{D} / \mathrm{L}$ values to a kinetic equation for Asp racemization. This indicates that the islands were ice covered for less than 3000 years if the basal temperature was $0^{\circ} \mathrm{C}$, and for less than 10000 years if it was $-5^{\circ} \mathrm{C}$.
\end{abstract}

The Novaya Zemlya islands are located on the continental shelf between the shallow Barents and Kara seas (Fig. 1). During the major Quaternary glaciations, the islands were situated under the central part of the Barents-Kara ice sheet that extended far onto the adjacent continent (Fig. 1) (Svendsen, Alexanderson et al. 2004). Accordingly, when Novaya Zemlya was ice-free, the BarentsKara ice sheet was either absent or confined to the western part of the Barents Sea. Permission to work on Novaya Zemlya has been difficult to obtain for several decades, and all samples used in this paper were collected in an area that is currently closed to western scientists. Some of the relevant geological record has also been destroyed by nuclear bomb tests. Nonetheless, some recent observations and results relating to the glacial and shoreline history from other parts of the islands have been published (Forman \& Polyak 1997; Serebryanny et al. 1998; Serebryanny \& Malyasova 1998; Forman et al.
1999; Zeeberg 2001; Zeeberg et al. 2001; Zeeberg et al. 2003).

During the summer of 1921, the Norwegian geologist O. Holtedahl (1922) led a scientific expedition to Novaya Zemlya, in which O.T. Grønlie participated as a Quaternary geologist. Grønlie (1924) stated that Novaya Zemlya had been glaciated several times, and he concluded, based on his findings of glacial erratics on mountain summits, that the ice sheet had been at least 1100-1200-m thick. He described "shorelines", and reported abundant driftwood and marine mollusc shells from the present sea level up to more than $200 \mathrm{~m}$ a.s.l., and collected molluscs for closer examination in the laboratory. In 1991, Mangerud searched in vain for these samples in museums in Oslo and Tromsø, and it was concluded that they had probably been lost during World War II. However, in December 2003 the mollusc samples unexpectedly turned up at the Tromsø University Museum. In view of 


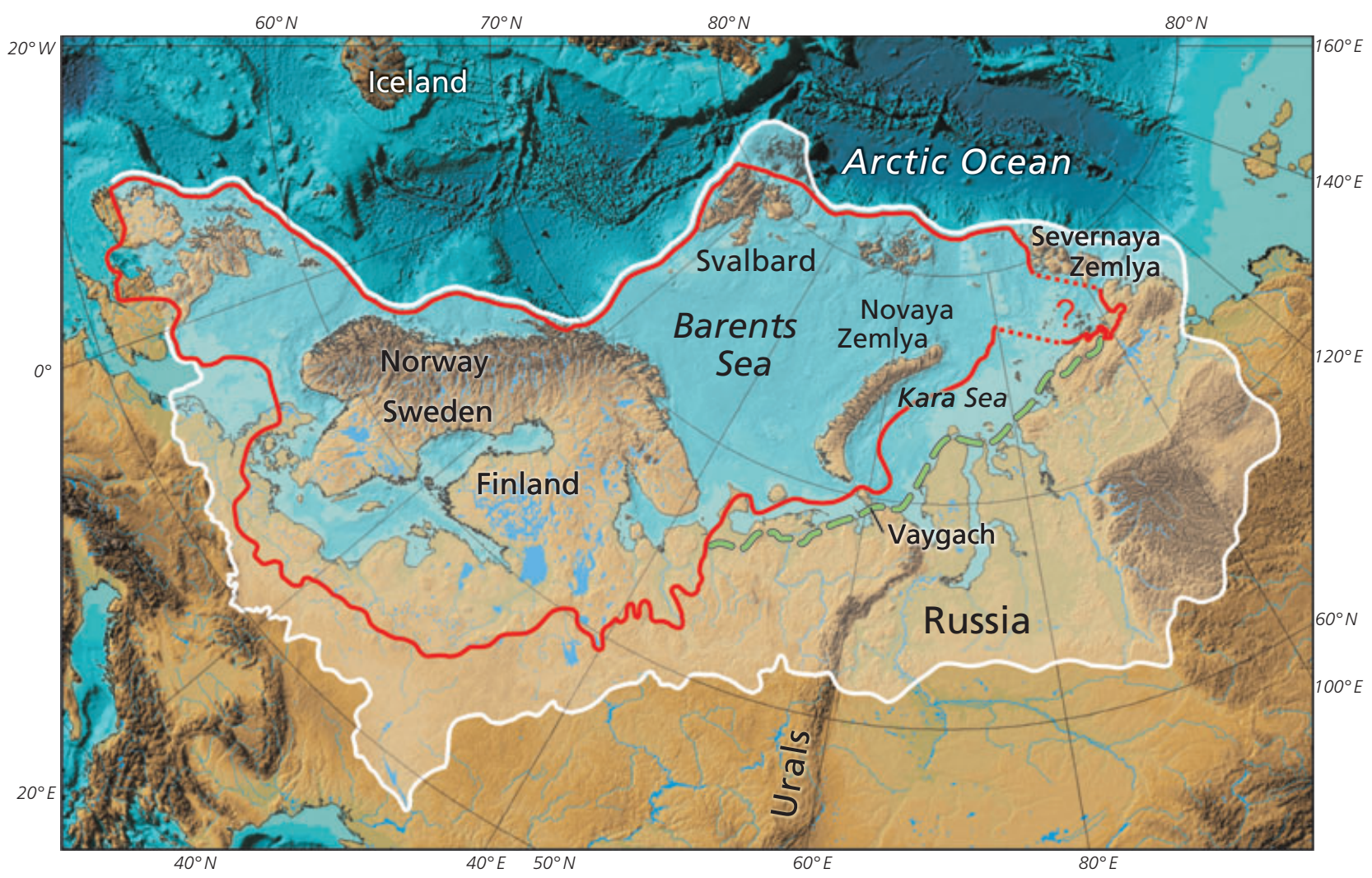

Fig. 1 Extent of the Eurasian ice sheet during the Last Glacial Maximum (red line) and marine isotope stage 6 (MIS 6) (white) (modified from Svendsen, Alexanderson et al. 2004). The extent of the ice sheet onto the Russian mainland during MIS 4 is also marked (green dashed line).

the reported high shorelines it was originally thought the samples could be used to reconstruct a major postglacial (Holocene) emergence of Novaya Zemlya, similar to that of eastern Svalbard (Bondevik et al. 1995), and indeed this is in harmony with the interpretations of Grønlie (1924). In the meantime, however, it had become clear that the Holocene marine limits at Novaya Zemlya are below about $18 \mathrm{~m}$ a.s.l. (Forman et al. 1999; Zeeberg et al. 2001), even though the islands had been covered by the ice sheet during the Last Glacial Maximum (LGM) (Zeeberg et al. 2001; Svendsen, Alexanderson et al. 2004). The implication of these recent results is that all molluscs collected by Grønlie at elevations higher than $18 \mathrm{~m}$ a.s.l. must have been overrun by glacial ice. This is supported by observations by Forman et al. (1999) and Zeeberg (2001), who described shell-bearing tills blanketing the landscape. For these reasons it became clear that the shell samples were not suited for studying Holocene sea-level changes, as previously thought.

Forman et al. (1999) obtained four ${ }^{14} \mathrm{C}$ ages in the range of 30-26 Ky from till and sub-till sediments from Nordenskiold Bay (Fig. 2), which they conservatively interpreted as minimum ages. Zeeberg (2001) reported two ${ }^{14} \mathrm{C}$ ages of about 43 and $40 \mathrm{Ky}$ from Cape Zhelaniya (Fig. 2), and four ${ }^{14} \mathrm{C}$ ages from Vaygach (Fig. 1) between 42 and $31 \mathrm{Ky}$, and also an optically stimulated luminescence (OSL) age of $47 \mathrm{Ky}$. Based on these ages, Zeeberg (2001) constructed a glaciation curve that indicates Novaya Zemlya was ice-free from 40 to 30 Kya.

In the present study we assume that the entire Novaya Zemlya archipelago was ice-covered during the LGM, as was concluded by Zeeberg et al. (2001) and Svendsen, Alexanderson et al. (2004). We emphasize that this assumption can be neither supported nor falsified with the material used in the present paper. The main theme of this paper is to determine at which time Novaya Zemlya was ice free prior to the LGM, and especially to determine if it was ice free during late marine isotope stage 3 (MIS 3). Therefore, we have radiocarbon dated many of Grønlie's mollusc samples. Furthermore, we have measured the amino acid racemization, and used the $\mathrm{D} / \mathrm{L}$ values to estimate the duration of the subsequent MIS 2 glaciation, following the method of Mangerud \& Svendsen (1992), but using the faster, racemizing aspartic acid. We also obtained a few new ages that relate to the Holocene 
Fig. 2 The Novaya Zemlya archipelago showing the locations mentioned in the text. Sites where we have dated mollusc shells are marked by stars. The approximate eastern boundary of the Last Glacial Maximum (LGM) Barents-Kara ice sheet is shown according to Svendsen, Alexanderson et al. (2004).

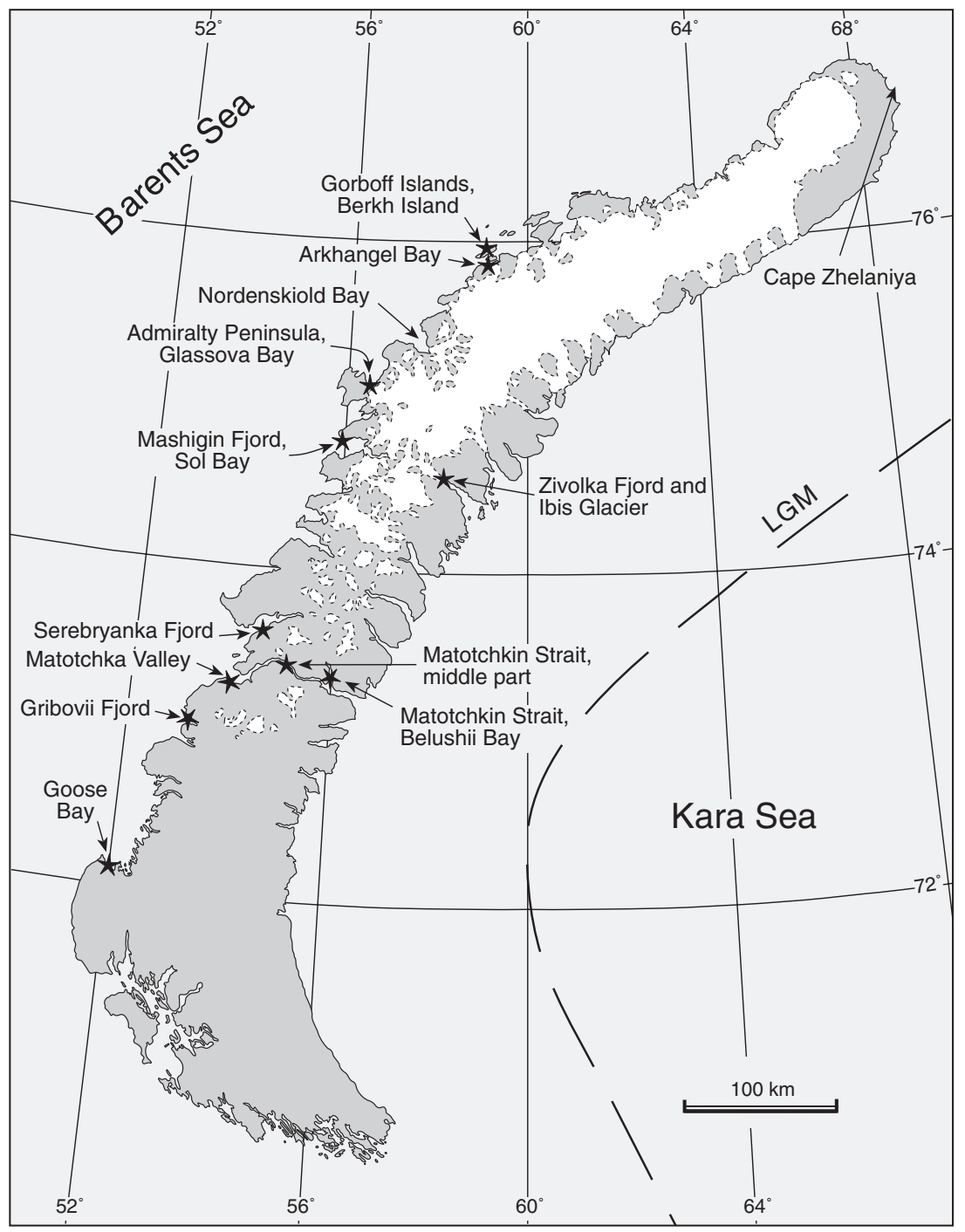

warm period and Holocene glacier re-advances, which we comment on briefly.

\section{Regional setting}

The Novaya Zemlya archipelago consists of two large and a number of small islands located between $70.5^{\circ}$ and $77^{\circ} \mathrm{N}$. The samples that we describe are from $72^{\circ}$ to $76^{\circ} \mathrm{N}$. Much of the northern part of Novaya Zemlya is covered by an elongated ice cap with summit elevations of about 800-1000 m a.s.l., and outlet glaciers that flow through valleys and fjords on both sides (Fig. 2). In the southern part of the archipelago, altitudes are generally below $500 \mathrm{~m}$ a.s.l.

The current and historical climates of the islands are described by Zeeberg (2001). They are influenced by warm North Atlantic water and air masses. Mean annual
(1955-1998) temperatures decreases from $-5.4^{\circ}$ to $-8.4^{\circ} \mathrm{C}$, and precipitation decreases from 396 to $329 \mathrm{~mm}$ from south to north at coastal stations on the west coast at $72^{\circ} 22^{\prime} \mathrm{N}$ and $76^{\circ} 11^{\prime} \mathrm{N}$, respectively (Zeeberg 2001 ).

\section{Methods}

\section{Radiocarbon dating}

Shells were analysed by accelerator mass spectrometry (AMS), except the valve from Berkh Island (T-17106), which was analysed by conventional methods at the Radiological Dating Laboratory, Norwegian University of Science and Technology, Trondheim, Norway. We carefully selected hard, compact shells for dating. Only a tiny central part of the umbo was analysed for AMS, and therefore the outer parts that had been exposed to the 
atmosphere were completely removed. As indicated in Table 1, the samples were dated at three different laboratories: the accelerator at Uppsala University, Sweden; Poznań Radiocarbon Laboratory, Poland; and the W.M. Keck Carbon Cycle Accelerator Mass Spectrometry Laboratory, University of California, Irvine, CA, USA. The analytical precision of the measured quantity of ${ }^{14} \mathrm{C}$ is asymmetrical once it is converted to years. This asymmetry is negligible when the error is small. In Table 1 this is indicated for the three samples as reported by the dating laboratories.

Almost all earlier published ${ }^{14} \mathrm{C}$ ages on marine materials around the Barents Sea were corrected for a marine reservoir age of $440{ }^{14} \mathrm{C}$ years (Mangerud \& Gulliksen 1975). For the Holocene samples, we use the more recently obtained values of $380 \pm 30$ years, relative to IntCal04, or a $\Delta R$ value of $20 \pm 30$ years (Mangerud et al. 2006). The reservoir ages for the period 50-20 Kya are unknown, and considering the sensitivity of such old samples to contamination by young ${ }^{14} \mathrm{C}$, we consider the reservoir age adjustment as minor compared with the total uncertainty for these old samples. In Table 1, all of the ages are reported without a marine-reservoir-age correction, and we use these uncorrected ages in all figures and discussions, unless otherwise specified.

We have not calibrated individual ${ }^{14} \mathrm{C}$ ages in the range of 45-30 Kya because the accuracy of the calibration is still very uncertain (van der Plicht et al. 2004; Fairbanks et al. 2005).

\section{Amino acid analyses}

Samples were prepared for amino acid analysis following standard procedures (Wehmiller \& Miller 2000). We focused on Mya truncata and to a lesser degree Hiatella, the two mollusc taxa that have been used most extensively for amino acid geochronology at high-latitude sites. The shells were cleaned by mechanical grinding and acid leaching, and were then demineralized in $20 \mu \mathrm{l}$ of $7 \mathrm{M}$ $\mathrm{HCl}$ per mg of $\mathrm{CaCO}_{3}$. All shells were analysed for the total hydrolysable amino acid (THAA) population of amino acids. The THAA was recovered by hydrolysing the sample solutions under $\mathrm{N}_{2}$ at $110^{\circ} \mathrm{C}$ for $6 \mathrm{~h}$. A subset of shells was prepared to isolate the intracrystalline proteins. As prescribed by Penkman et al. (2008), powdered shell $(90-425 \mu \mathrm{m})$ was soaked in $12 \% \mathrm{NaOCl}$ for $48 \mathrm{~h}$ to decompose the accessible intercrystalline amino acids. Once isolated, the intracrystalline proteins were analysed for two amino acid fractions: the total hydrolysable amino acid (intra-THAA) population, and the free amino acid (intra-FAA) fraction, which was prepared by omitting the hydrolysis step. All sample solutions were evaporated to dryness in vacuo, and were then rehydrated in $0.01 \mathrm{M} \mathrm{HCl}$ containing an internal standard of L-homo-arginine.

The chromatographic instrumentation and procedure used to separate amino acid enantiomers is presented by Kaufman \& Manley (1998). The average analytical uncertainty (internal reproducibility) measured by the coefficient of variation for multiple injections of laboratory standards is typically between 3 and $5 \%$ for the D/L values. For this study, we focused on aspartic acid (Asp) and glutamic acid (Glu), two amino acids that are among the most abundant in mollusc protein, and are the best resolved chromatographically. More accurately, Asp and Glu may include a small component of asparagine and glutamine, respectively, which were converted to Asp and Glu during laboratory hydrolysis. Asp and Glu elute during the first 30 min of the sample run, and span most of the range of racemization rates.

Duplicate subsamples of seven Hiatella and 30 Mya shells were analysed for the conventional THAA amino acids. The difference between the $\mathrm{D} / \mathrm{L}$ values of the duplicate subsamples, each injected onto the HPLC column once, averaged 2\% for Asp and 4\% for Glu (as normalized with the mean D/L value for each sample). None of the analytical results were rejected, and we report only the mean D/L value of the two replicate samples (Table 2). All of the Hiatella shells and a representative selection of 19 Mya shells were analysed for their intracrystalline proteins. An aliquot of powdered and bleached shell was used for each of the intra-THAA and intra-FAA fractions, and each was analysed once on the HPLC column.

\section{Material, observations and results}

\section{Samples}

All samples were collected and described by Grønlie (1924), and we have retained his names for the geographical sites. Table 1 lists the page and line number for the description of each sample in Grønlie's book (1924). He described 66 shell sites, of which 57 are represented in the collections at Tromsø University Museum. We selected the best-preserved shells and did not use all of the available samples. Details on taxa and the number of specimens are given in Table 3. Although not directly described by Grønlie (1924), it appears that all of the specimens were collected from near the surface of the deposits. He did not describe any excavating or clearing of stratigraphical sections.

Grønlie did not number the samples: they were found wrapped in the original paper, and the site name and other information were written on the wrapping paper. We have given all samples individual numbers in the order in which they are treated in Grønlie (1924), with 


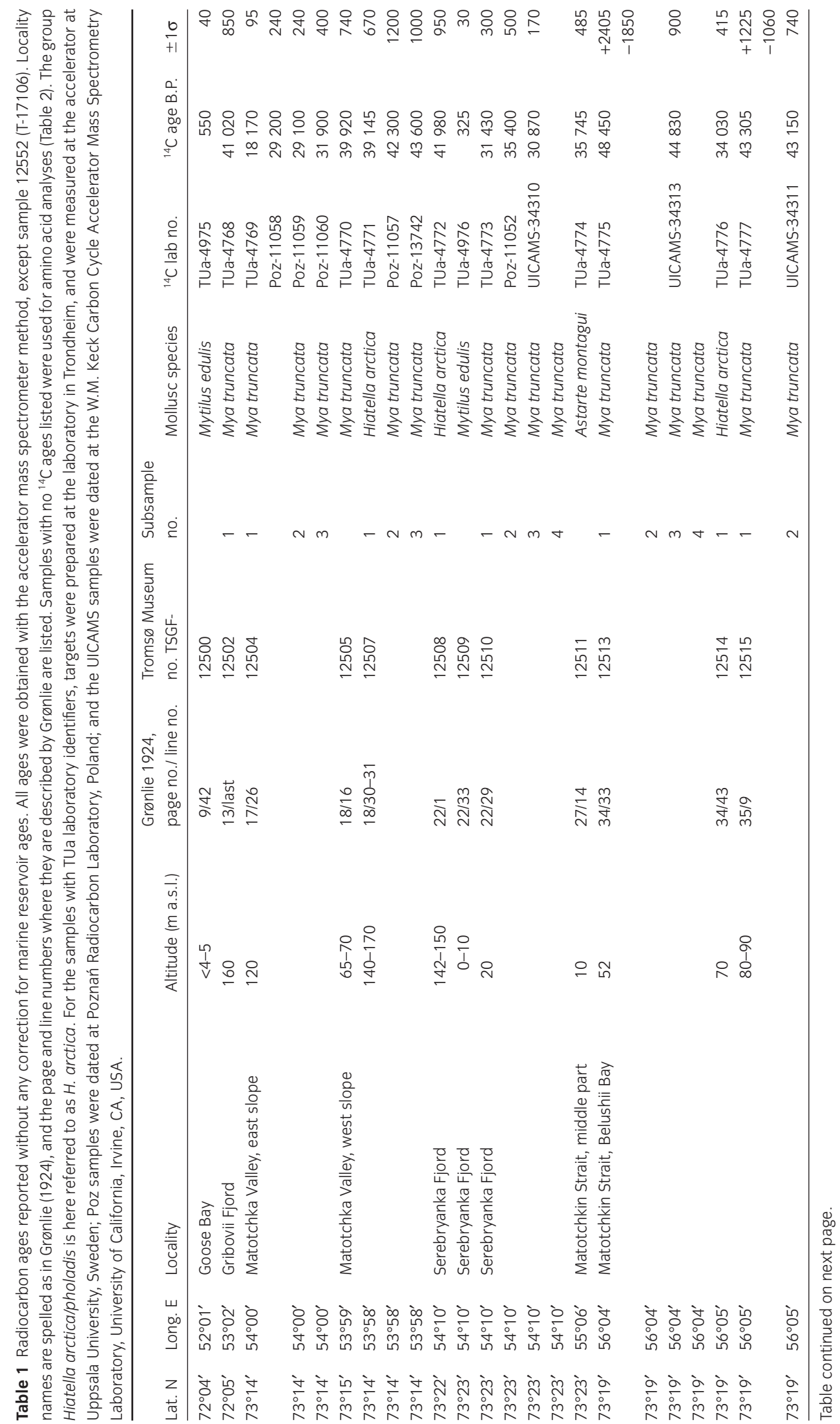




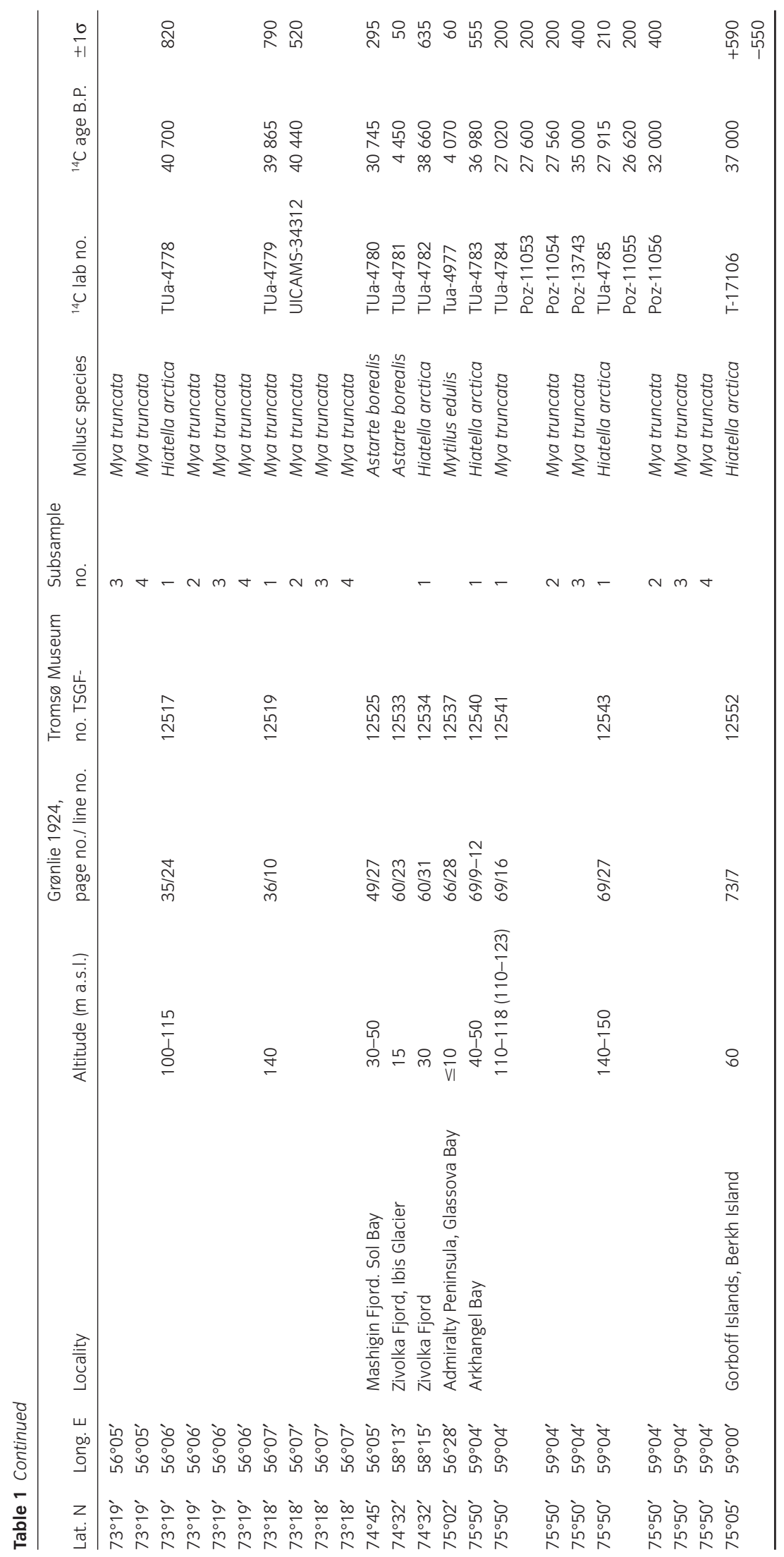


Table 2 Amino acid results. The ${ }^{14} \mathrm{C}$ ages from Table 1 are included for comparison.

\begin{tabular}{|c|c|c|c|c|c|c|c|c|c|c|c|}
\hline \multirow{2}{*}{$\begin{array}{l}\text { AAR lab } \\
\text { no. UAL- }\end{array}$} & \multirow{2}{*}{$\begin{array}{l}\text { Sample } \\
\text { no. TSGF- }\end{array}$} & \multirow{2}{*}{$\begin{array}{l}\text { Sub- } \\
\text { sample }\end{array}$} & \multirow[b]{2}{*}{ Genus } & \multirow[b]{2}{*}{${ }^{14} \mathrm{C}$ age B.P. } & \multirow[b]{2}{*}{ $\pm 1 \sigma$} & \multicolumn{2}{|c|}{ Conventional THAA } & \multicolumn{2}{|c|}{ Intracrystalline FAA } & \multicolumn{2}{|c|}{ Intracrystalline THAA } \\
\hline & & & & & & $\mathrm{D} / \mathrm{L} \mathrm{Asp}$ & D/L Glu & D/L Asp & D/L Glu & $\mathrm{D} / \mathrm{L} \mathrm{Asp}$ & D/L Glu \\
\hline 5007 & 12504 & 1 & Mya & 29200 & 240 & 0.134 & 0.030 & 0.274 & 0.134 & 0.147 & 0.045 \\
\hline 5008 & & 2 & Mya & 29100 & 240 & 0.149 & 0.065 & 0.291 & 0.152 & 0.160 & 0.055 \\
\hline 5009 & & 3 & Mya & 31900 & 400 & 0.138 & 0.044 & 0.271 & 0.148 & 0.160 & 0.065 \\
\hline 5004 & 12507 & 1 & Hiatella & 39145 & 670 & 0.211 & 0.062 & 0.493 & 0.228 & 0.234 & 0.081 \\
\hline 5005 & & 2 & Mya & 42300 & 1200 & 0.257 & 0.055 & 0.467 & 0.227 & 0.245 & 0.067 \\
\hline 5006 & & 3 & Mya & 43600 & 1000 & 0.232 & 0.057 & 0.509 & 0.252 & 0.261 & 0.079 \\
\hline 5070 & 12508 & 1 & Hiatella & 41980 & 950 & 0.142 & 0.036 & 0.338 & 0.262 & 0.153 & 0.061 \\
\hline 5065 & 12510 & 1 & Mya & 31430 & 300 & 0.175 & 0.029 & 0.264 & 0.113 & 0.167 & 0.047 \\
\hline 5066 & & 2 & Mya & 35400 & 500 & 0.174 & 0.046 & 0.296 & 0.236 & 0.181 & 0.050 \\
\hline 5067 & & 3 & Mya & 30870 & 170 & 0.194 & 0.038 & 0.303 & 0.201 & 0.188 & 0.046 \\
\hline 5068 & & 4 & Mya & & & 0.182 & 0.054 & & & & \\
\hline 5081 & 12513 & 1 & Mya & 48450 & 2405 & 0.371 & 0.180 & 0.762 & 0.386 & 0.445 & 0.215 \\
\hline 5082 & & 2 & Mya & & & 0.339 & 0.122 & & & & \\
\hline 5083 & & 3 & Муа & 44830 & 900 & 0.395 & 0.157 & 0.751 & 0.422 & 0.448 & 0.199 \\
\hline 5084 & & 4 & Mya & & & 0.330 & 0.132 & & & & \\
\hline 5069 & 12514 & 1 & Hiatella & 34030 & 415 & 0.229 & 0.077 & 0.529 & 0.362 & 0.252 & 0.108 \\
\hline 5061 & 12515 & 1 & Mya & 43305 & 1225 & 0.380 & 0.130 & 0.643 & 0.362 & 0.428 & 0.173 \\
\hline 5062 & & 2 & Mya & 43150 & 740 & 0.234 & 0.056 & 0.391 & 0.200 & 0.250 & 0.079 \\
\hline 5063 & & 3 & Mya & & & 0.231 & 0.066 & & & & \\
\hline 5064 & & 4 & Муа & & & 0.361 & 0.147 & & & & \\
\hline 5073 & 12517 & 1 & Hiatella & 40700 & 820 & 0.214 & 0.053 & 0.515 & 0.283 & 0.249 & 0.088 \\
\hline 5074 & & 2 & Mya & & & 0.235 & 0.044 & & & & \\
\hline 5075 & & 3 & Mya & & & 0.212 & 0.047 & & & & \\
\hline 5076 & & 4 & Mya & & & 0.239 & 0.047 & & & & \\
\hline 5077 & 12519 & 1 & Mya & 39865 & 790 & 0.256 & 0.061 & 0.506 & 0.292 & 0.271 & 0.086 \\
\hline 5078 & & 2 & Mya & 40440 & 520 & 0.225 & 0.073 & 0.451 & 0.266 & 0.253 & 0.074 \\
\hline 5079 & & 3 & Mya & & & 0.219 & 0.046 & & & & \\
\hline 5080 & & 4 & Mya & & & 0.227 & 0.080 & & & & \\
\hline 5071 & 12534 & 1 & Hiatella & 38660 & 635 & 0.183 & 0.052 & 0.507 & 0.281 & 0.241 & 0.118 \\
\hline 5072 & 12540 & 1 & Hiatella & 36980 & 555 & 0.145 & 0.047 & 0.349 & 0.287 & 0.171 & 0.069 \\
\hline \multirow[t]{2}{*}{4997} & 12541 & 1 & Mya & 27020 & 200 & 0.188 & 0.047 & 0.324 & 0.100 & 0.203 & 0.059 \\
\hline & & 1 & Mya & 27600 & 200 & & & & & & \\
\hline 4998 & & 2 & Mya & 27560 & 200 & 0.191 & 0.045 & 0.359 & 0.159 & 0.206 & 0.061 \\
\hline 4999 & & 3 & Mya & 35000 & 400 & 0.183 & 0.044 & 0.303 & 0.088 & 0.189 & 0.052 \\
\hline \multirow[t]{2}{*}{5000} & 12543 & 1 & Hiatella & 27915 & 210 & 0.170 & 0.053 & 0.314 & 0.151 & 0.184 & 0.069 \\
\hline & & 1 & Hiatella & 26620 & 200 & & & & & & \\
\hline 5001 & & 2 & Mya & 32000 & 400 & 0.197 & 0.045 & 0.355 & 0.163 & 0.214 & 0.063 \\
\hline 5002 & & 3 & Mya & & & 0.164 & 0.043 & 0.331 & 0.155 & 0.195 & 0.057 \\
\hline 5003 & & 4 & Mya & & & 0.181 & 0.045 & & & & \\
\hline
\end{tabular}

the prefix TSGF for the palaeontological collections at the Tromsø University Museum. We are confident that all samples used here are correctly identified in Grønlie (1924). Most of Grønlie's samples consist of multiple mollusc shells. Each specimen selected by us was given a subsample number (e.g., 12504-1, Table 1). We always subsampled the same part of the mollusc, mainly the umbo, so that each subsample represents a unique individual, which is crucial for the evaluation of the dating results. Two radiocarbon-dated subsamples (TUa-4768 and TUa-4770) were lost in the mail, and were therefore not analysed for amino acids.

Grønlie's scientific background included studies of glacio-isostatic uplifted, postglacial shorelines from northern Norway, and apparently he assumed that all molluscs and driftwood he found on Novaya Zemlya were also of postglacial age. His descriptions were too sparse for any reinterpretation of the stratigraphic context of the shells, including whether they were collected from till or sub-till sediments. Nevertheless, as mentioned in the introduction, we postulate that all samples yielding ${ }^{14} \mathrm{C}$ ages older than $20 \mathrm{Ky}$ have been overrun by glacial ice, although this is contrary to Grønlie's assumptions.

\section{Macrofossils}

The specimens collected by Grønlie have been re-examined, and in some cases re-identified. Recently 


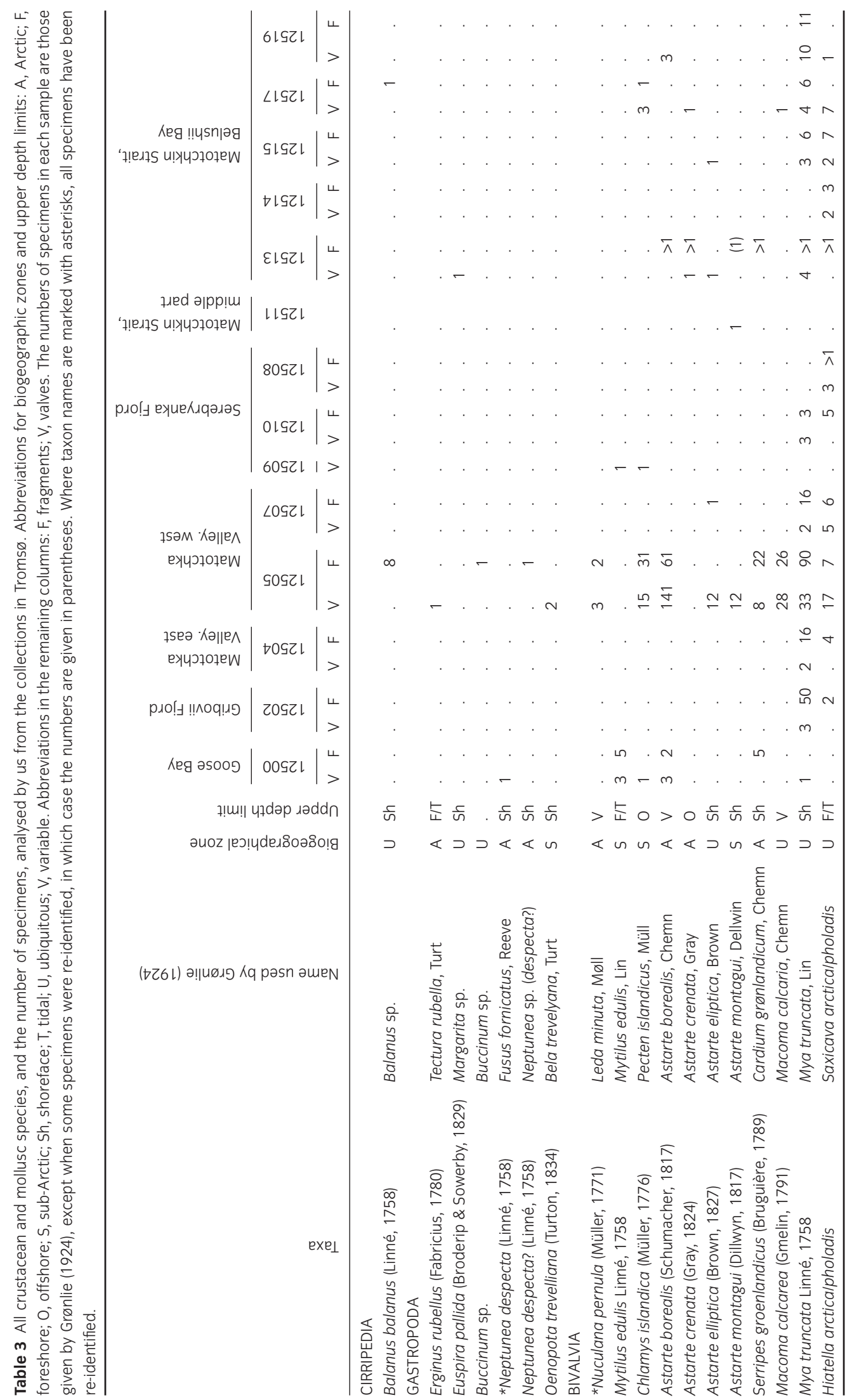




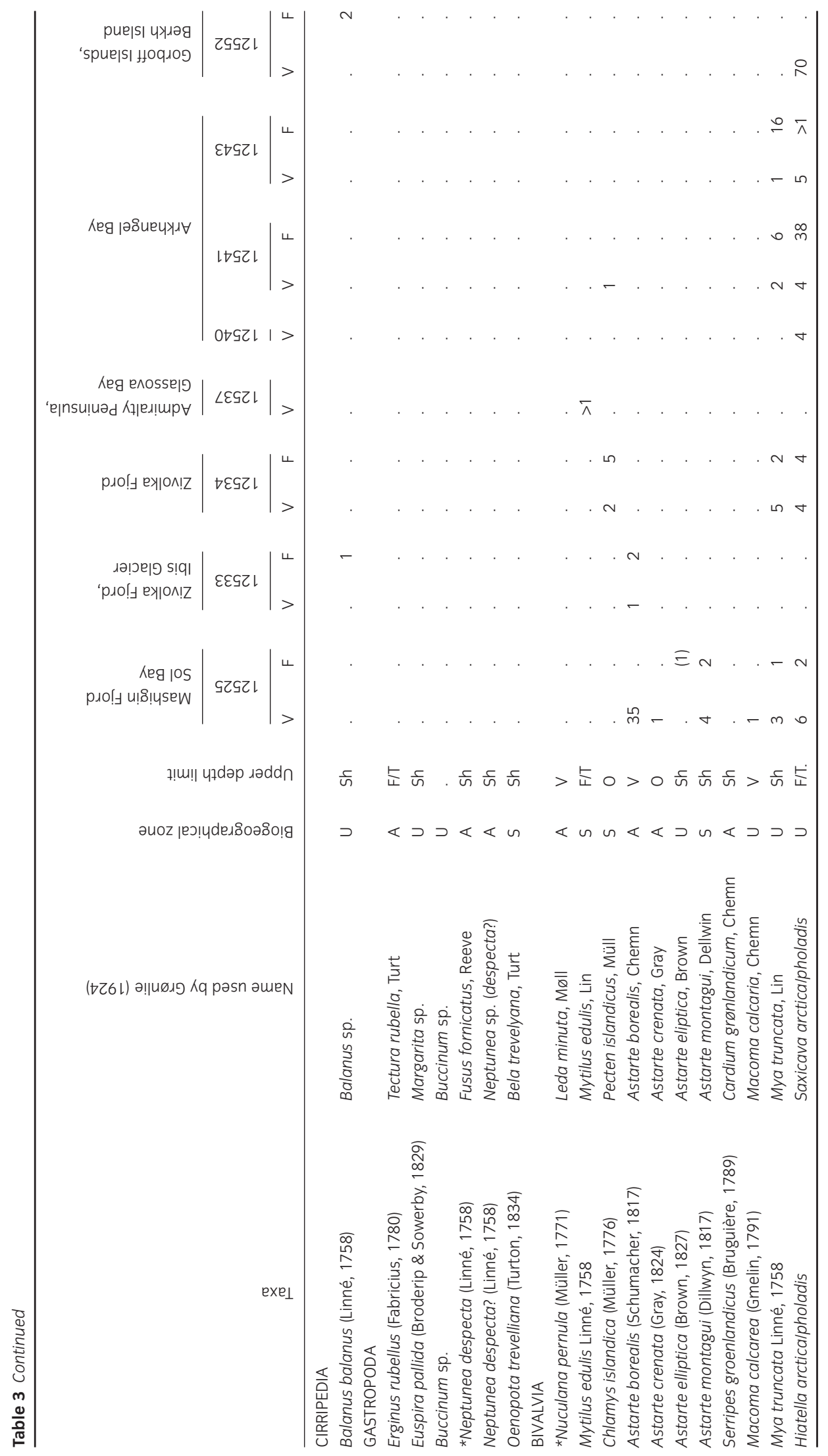


used scientific names are listed in Table 3 together with those used by Grønlie (1924). None of the bivalve specimens seem to have been found as conjugated valves. The samples often include whole valves and specimens of the rather thin-shelled Nuculana pernula, Chlamys islandica and Serripes groenlandicus.

All of the collected species live in Arctic and/or subArctic environments, and thus in environments similar to those in the region today. Ten out of the 22 samples include species with sub-Arctic northern boundaries. These samples are significantly more diverse than those made up of only Arctic species (Table 3), suggesting two distinct biofacies. Whereas the Arctic faunas have been sampled from near sea level and up to $239 \mathrm{~m}$ a.s.l. (of which we have dated samples up to $170 \mathrm{~m}$ a.s.l.), the sub-Arctic faunas are all from below $142 \mathrm{~m}$ a.s.l.

In Arctic environments many molluscan taxa prefer to live in shallow waters (Funder et al. 2002). With two exceptions, the upper limit of habitat depth is within the shore face-tidal zone. The abundance of deeper water molluscs is generally low. Probably all specimens originate from shallow coastal habitats near the site where they were found.

\section{Results of ${ }^{14} \mathrm{C}$ dating}

We obtained $37{ }^{14} \mathrm{C}$ ages of mollusc shells (Table 1), of which 33 gave ages in the range of $48-26{ }^{14} \mathrm{C} \mathrm{Ky}$. All dated shells collected above $15 \mathrm{~m}$ a.s.l. yielded ages older than $26 \mathrm{Ky}$, supporting other evidence that the Holocene marine limit is low (Forman et al. 1999; Zeeberg et al. 2001).

Four samples, collected between 0 and $15 \mathrm{~m}$ a.s.l., yielded Holocene ages. A specimen of Astarte borealis collected on the surface of the Ibis Glacier indicates that at $4450 \pm 50{ }^{14} \mathrm{C}$ years B.P. $(4900-4500 \mathrm{cal}$ years B.P.; Hughen et al. 2004) the glacier was smaller than in 1921, consistent with results from Svalbard (Svendsen \& Mangerud 1997).

\section{Geographic and stratigraphic occurrence of Mytilus edulis}

Mytilus edulis shells from the Holocene warm period are often found beyond its current distribution in the Barents Sea area. We therefore dated three specimens from Grønlie's collections. The two southern samples yielded present-day ages when corrected for reservoir age, and show that Mytilus currently lives in the north to at least $73.5^{\circ} \mathrm{N}$. This is well north of $71.3^{\circ} \mathrm{N}$, where Galkin (1998) documented living specimens at Novaya Zemlya for the period 1870-1930. The northernmost sample from Admiralty Peninsula, $75^{\circ} \mathrm{N}$, yielded an age of $4070 \pm 60{ }^{14} \mathrm{C}$ years B.P. (calibrated as 4170-3970 cal years B.P.; Hughen et al. 2004), which is slightly younger than the youngest Mytilus in south-east Svalbard (Hjort et al. 1995), and at the young end of ages from western Svalbard (Salvigsen et al. 1992).

\section{Amino acid results}

The D/L values for the two amino acids (Asp and Glu) and the various amino acid fractions can be compared with each other to assess the internal consistency of the racemization results, because the diagenetic pathways should lead to strongly covariant $\mathrm{D} / \mathrm{L}$ values among the various amino acid populations. The Asp D/L and Glu D/L values are generally well correlated in the conventionally prepared THAA fraction (Fig. 3a), and the correlation is improved for the intracrystalline fraction (intra-THAA; Fig. 3b). D/L values show an expected systematic taxonomic effect between Mya and Hiatella that is also better expressed in the intracrystalline fraction. The $\mathrm{D} / \mathrm{L}$ values in the conventionally prepared and the intracrystalline THAA fractions are similar (Fig. 3c), although slightly higher in the intra-THAA. This indicates that the THAA fraction is dominated by the intracrystalline amino acids, and that the free amino acids are more completely retained in the intracrystalline fraction. The correlation between the D/L values of the THAA and the D/L values of the FAA in the intracrystalline fraction is also strong, attesting to the integrity of this fraction for amino acid geochronology (Penkman et al. 2008) (Fig. 3d). Taken together the results exhibit a high degree of intercorrelation, indicating that the shells are well suited for amino acid geochronology.

\section{Localities}

The following sections include short notes on each locality based on the descriptions by Grønlie (1924). The sites are described in the same sequence as in Grønlie (1924), which is also followed by the Tromsø University Museum numbering of the samples (Table 1). We will discuss most of the ${ }^{14} \mathrm{C}$ results here.

\section{Goose Bay}

Only one shell of M. edulis was dated from this site. It was collected from a flight of beaches rising from the sea to 4-5 $\mathrm{m}$ a.s.l. Grønlie commented that "the shells looked recent", which is supported by the ${ }^{14} \mathrm{C}$ age yielding $550 \pm 40{ }^{14} \mathrm{C}$ years B.P. By subtracting the ${ }^{14} \mathrm{C}$ age of tree rings from 1921 ( $130 \pm 7{ }^{14} \mathrm{C}$ years; Reimer et al. 2004), the new age is $420 \pm 41{ }^{14} \mathrm{C}$ years B.P., i.e. close to the present-day marine reservoir age. 

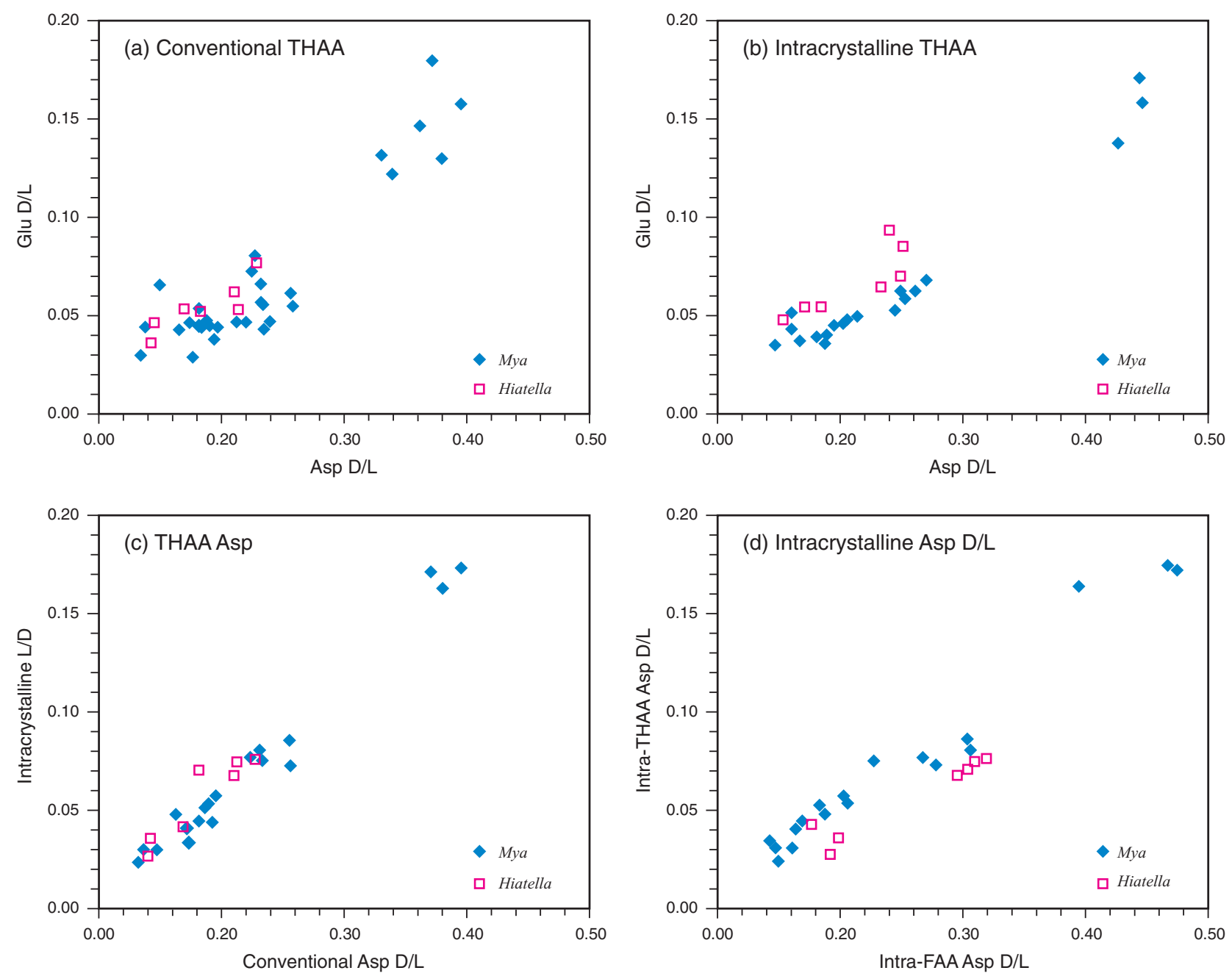

Fig. 3 Scatter plots of D/L values among amino acid fractions. Note the different signatures for Mya truncata and Hiatella arctica. (a) Extent of racemization (D/L) for glutamic acid (Glu) and aspartic acid (Asp) measured in the conventionally prepared, total hydrolysable amino acid (THAA) population of shells. (b) Asp versus Glu D/L for the intracrystalline fraction. (c) Comparison between Asp D/L in conventionally prepared versus the intracrystalline fraction of shells. (d) Comparison between Asp D/L in the THAA versus the free amino acid (FAA) populations of the intracrystalline fraction. The strong correlation between D/L values in the two amino acids (Asp and Glu) and various amino acid fractions attests to the integrity of the amino acid geochronology results.

\section{Gribovii Fjord}

Grønlie noted that "several shore-lines were fairly well developed" here (1924: 13). He found three whole valves and 50 fragments of $M$. truncata, and two fragments of Hiatella $10 \mathrm{~m}$ above a river and $160 \mathrm{~m}$ a.s.l. All specimens are moderately weathered and are missing the periostracum. We obtained a ${ }^{14} \mathrm{C}$ age of about $41 \mathrm{Ky}$ from one specimen of Mya. The subsamples for amino acid analyses were lost in the mail.

\section{Matotchka Valley}

Matotchka Valley is a short, wide valley that opens to the south shore of the Matotchkin Strait, near its western entrance. A broad end moraine crosses the valley. Grønlie collected a few Mya and Hiatella shells on this moraine at $120 \mathrm{~m}$ a.s.l. on the east side of the valley (sample 12504). The specimens are weathered and generally exfoliated. The three analysed specimens yielded ${ }^{14} \mathrm{C}$ ages ranging from 32 to $29 \mathrm{Ky}$. On the west slope, the moraine comprises two ridges. The northern ridge "consists for the greater part of clay with a top layer of sand, gravel and pebbles" (Grønlie 1924: 17). Here, Grønlie described a rich molluscan fauna (65-70 $\mathrm{m}$ a.s.l.) with numerous individuals (mostly fragments) of 13 taxa, including many large $C$. islandica. The specimens, which are slightly weathered, occasionally retain fragments of the periostracum. One specimen of Mya was analysed. The 
southern ridge "consists of gravel and pebbles; clay has not been observed" (Grønlie 1924: 18). Here (140$170 \mathrm{~m}$ a.s.l.), he found 30 individuals (mostly fragments) of three species, among which three specimens have been dated. All shells from the west slope yielded older ${ }^{14} \mathrm{C}$ ages (44-39 Ky) than from the east slope.

\section{Serebryanka Fjord}

Serebryanka Fjord is an inlet just north of the western entrance to Matotchkin Strait. Grønlie states that, from the sea and up to $180 \mathrm{~m}$ a.s.l., marine sediments are exposed on flat areas and rock detritus in the old cliffs; till is exposed only above $180 \mathrm{~m}$ a.s.l. (1924: 21). At $199 \mathrm{~m}$ a.s.l. he described “. . . a very distinct line with a beach of water-worn pebbles of quartzites and dolomites" (1924: 21). Along this profile from 0-200 ma.s.l. he described shells only at 142-150 m a.s.l. (sample 12508). The shells are weathered and are mostly small fragments. One of these was ${ }^{14} \mathrm{C}$ dated to about $42 \mathrm{Ky}$. In the vicinity of this profile, Grønlie collected shells at about $20 \mathrm{~m}$ a.s.l. (sample 12510). Three ${ }^{14} \mathrm{C}$ analyses of different individuals yielded ages from 35 to $31 \mathrm{Ky}$.

Grønlie also collected one valve of $M$. edulis here. His description of the site is poor, but the altitude is between 0 and $10 \mathrm{~m}$ a.s.l. The specimen in the collection looked recent, which was confirmed by the ${ }^{14} \mathrm{C}$ age. Once the ${ }^{14} \mathrm{C}$ age of tree rings from 1921 (Reimer et al. 2004) is subtracted the age is $195 \pm 31$ c years, which is less than expected for the marine reservoir age (Mangerud et al. 2006). However, Forman \& Polyak (1997) also reported some young reservoir ages from Novaya Zemlya.

\section{Matotchkin Strait, middle part}

On the south shore of the strait, Grønlie listed multiple shorelines up to $92 \mathrm{~m}$ a.s.l. on a till surface. However, he found only two shells, at 85 and $10 \mathrm{~m}$ a.s.l. The latter specimen (12511) was an Astarte with part of the periostracum preserved. It was dated because it was collected near sea level, and was therefore a candidate for a postglacial age. However, it yielded an age of about $35 \mathrm{Ky}$.

\section{Matotchkin Strait, Belushii Bay}

The Belushii Bay is a 12 -km-long inlet on the northern shore of the Matotchkin Strait, near its eastern entrance. In a wide valley on the eastern side of the bay, Grønlie (1924) described shells at elevations ranging from 52 to $142 \mathrm{~m}$ a.s.l. He also found driftwood up to $16 \mathrm{~m}$ a.s.l.

The shells collected at $52 \mathrm{~m}$ a.s.l. (12513; Table 1) were found in the channel of the outlet river from a lake. They are poorly preserved. Two specimens were dated. Further upstream "along the river above the lake shell fragments were to be seen everywhere" (Grønlie 1924: 34). He collected the next sample at $70 \mathrm{~m}$ a.s.l., where he found numerous weathered Hiatella (Table 3), among which one (12514) has been dated to $34 \mathrm{Ky}$. Between 70 and $80 \mathrm{~m}$ a.s.l. the river runs in a canyon, but from $80 \mathrm{~m}$ a.s.l it is gentler, and from here he collected another sample (12515). Two of these rather heavily weathered specimens were dated. Between 90 and $100 \mathrm{~m}$ a.s.l. he found "plenty" rather heavily weathered M. truncata and Hiatella shells, but we did not analyse any of these. Grønlie reported a more diverse fauna at 100-115 m a.s.l. (sample 12517; Tables 1 and 3), and then the highest shells were located at 130-142 m a.s.l. (12519). Both samples contain specimens of variable preservation. One valve from 100-1 $15 \mathrm{~m}$ a.s.l. and two from $140 \mathrm{~m}$ a.s.l. were dated. All of the dated shells from Belushii Bay yielded old ${ }^{14} \mathrm{C}$ ages of $48-39 \mathrm{Ky}$, except the aforementioned Hiatella with an age of $34 \mathrm{Ky}$. The D/L values (Table 2) indicate that this Hiatella is older than $34 \mathrm{Ky}$.

\section{Mashigin Fjord, Sol Bay}

Sol Bay is on the northern shore of the wide western part of Mashigin Fjord. Here Grønlie (1924) described several sites with shells. He also reported well-preserved shorelines formed in unconsolidated sediments, despite the active solifluction. If this is correct it indicates that the shorelines survived below the overrunning ice sheet. At 30-50 m a.s.l., he found 35 slightly weathered valves of A. borealis, although none with their periostracum preserved. We dated one to about 31 Kya (sample 12525).

\section{Zivolka Fjord, Ibis Glacier}

The Ibis Glacier is an outlet of the central glacier plateau, which had an ice divide at about $350 \mathrm{~m}$ a.s.l. (Grønlie 1924). The Ibis Glacier flows eastward, terminating in Zivolka Fjord on the east coast. Twelve slightly weathered shell fragments were found on the surface of the glacier at about $15 \mathrm{~m}$ a.s.l. (sample 12533). We postulate that the glacier picked them up from its bed, and that the age of $4450 \pm 50{ }^{14} \mathrm{C}$ years B.P. indicates a period when the glacier front had retreated further back than its position in 1921 .

\section{Zivolka Fjord}

Several slightly to moderately weathered shells were found at the head of this east-coast fjord at $30 \mathrm{~m}$ a.s.l., including C. islandica (sample 12534). We obtained an age of about $38 \mathrm{Ky}$ for a Hiatella shell from this sample. 


\section{Admiralty Peninsula, Glassova Bay}

Glassova Bay is located on the northern and inner part of the Admiralty Peninsula. Here Grønlie described M. edulis up to $10 \mathrm{~m}$ a.s.l. We dated a well-preserved specimen to $4070 \pm 60{ }^{14} \mathrm{C}$ years B.P. (sample 12537).

\section{Arkhangel Bay}

The Arkhangel Bay is located between the mainland and the Berkh and Litchutin islands. Grønlie surveyed what he described as 17 shorelines between 3 and $239 \mathrm{~m}$ a.s.l. on a ridge on the mainland shore of the bay, and collected moderately to heavily weathered and fragmented shells at different altitudes. We obtained eight ${ }^{14} \mathrm{C}$ ages for six specimens; the oldest age $(37 \mathrm{Ky})$ was from the lowermost sample collected at 40-50 m a.s.l. (sample 12540). Three shells from the altitudes 110-118 and 140$150 \mathrm{~m}$ a.s.l. (samples 12541 and 12543) yielded ages of about $27 \mathrm{Ky}$, two of which were dated at both the Trondheim and Poznań laboratories, and returned identical ages. The last two shells yielded ages of 35 and $32 \mathrm{Ky}$.

\section{Gorboff Islands, Berkh Island}

Grønlie stated that at $60 \mathrm{~m}$ a.s.l. "the shells lay on the surface in great masses" (Grønlie 1924: 73). These were mainly moderately weathered whole valves of Hiatella, but also included Balanus balanus. We dated one Hiatella shell to about 37 Kya (sample 12552).

\section{Discussion}

\section{Are any of the finite ${ }^{14} \mathrm{C}$ ages real?}

A key question for the interpretation of the geological history is whether any of the finite ${ }^{14} \mathrm{C}$ ages are real, or whether all samples were contaminated with younger ${ }^{14} \mathrm{C}$ so that the ages should be considered minimum ages. This problem has been much discussed for samples that are older than about $20 \mathrm{Ky}$, because the low ${ }^{14} \mathrm{C}$ activity makes them very sensitive to contamination by young or modern ${ }^{14} \mathrm{C}$. Although it is impossible to resolve this issue unequivocally, we will examine the problem from multiple angles. It should be noted that only the core of the umbo of hard shells, which is best protected from contamination, was used for the AMS analysis. Thus, AMS samples should be less exposed to potential contamination than samples for conventional ${ }^{14} \mathrm{C}$ dating in which more of the shell is used.

The first batch of samples submitted for ${ }^{14} \mathrm{C}$ dating to the Trondheim laboratory included a shell that gave an age of about $18 \mathrm{Ky}$ (sample 12504; TUa-4769, Table 1).
We found this age unlikely, and resubmitted a piece from the same specimen to the Poznań Laboratory, together with two other specimens from the original Trondheim batch. The replicate subsample yielded an age of $29.2 \mathrm{Ky}$ (Poz-11058), whereas the two other sets of subsamples yielded almost identical ages from the two laboratories: 27.0 vs. $27.6 \mathrm{Ky}$ (sample 12541; TUa-4784/Poz-11053) and 27.9 vs. $26.6 \mathrm{Ky}$ (sample 12543; TUa-4785/Poz$11055)$. We therefore conclude that the younger age of $18 \mathrm{Ky}$ was the result of a laboratory error. The two other sets of replicate samples demonstrate that ${ }^{14} \mathrm{C}$ ages are reproducible from slightly different parts of a specimen in Grønlie's collection.

In several cases we also submitted more than one specimen from a sample in Grønlie's collection (i.e., samples given different subsample numbers but the same TSGF number in Table 1), and we were careful to submit only one subsample from each individual. Certainly individuals in one sample may have different ages, especially because we postulate that glaciers have overrun all localities, and thus shells of different ages could have been mixed. We nevertheless find it likely that most specimens in a sample have similar ages. In general, the ${ }^{14} \mathrm{C}$ ages of the subsamples show a strong correlation among different individuals from each collection (Fig. 4): for five pairs of samples the ${ }^{14} \mathrm{C}$ ages are virtually identical. If the samples were heavily contaminated with young carbon, we would expect a larger and random spread of the ages.

Amino acid racemization is a chemical reaction that progresses independently of the decay of ${ }^{14} \mathrm{C}$, and therefore can be used to assess the reliability of the ${ }^{14} \mathrm{C}$ ages. The rate of racemization is controlled by temperature, and is also different between different mollusc species. The D/L value thus depends on the age of the shell, the ambient temperature since the mollusc died and the studied species. Regardless of the precise rate of racemization, however, the $\mathrm{D} / \mathrm{L}$ values offer a reliable relativeage index for shells of the same species that have experienced the same temperature history since the mollusc died.

We focus on the results for Mya shells because we have more measurements on this taxon (Table 2) to evaluate age-dependent trends, and in order to avoid speciesrelated variations in the rate of racemization. We also concentrate on Asp because this amino acid racemizes faster than Glu, and is therefore a more sensitive chronometer at low temperatures (Goodfriend et al. 1996). The measured Asp D/L values generally increase with increasing ${ }^{14} \mathrm{C}$ age (Fig. 5), indicating that the ${ }^{14} \mathrm{C}$ ages approximate the real age of the shells. This interpretation is bolstered by the evidence for the integrity of the shells for the amino acid geochronology described above. Three 


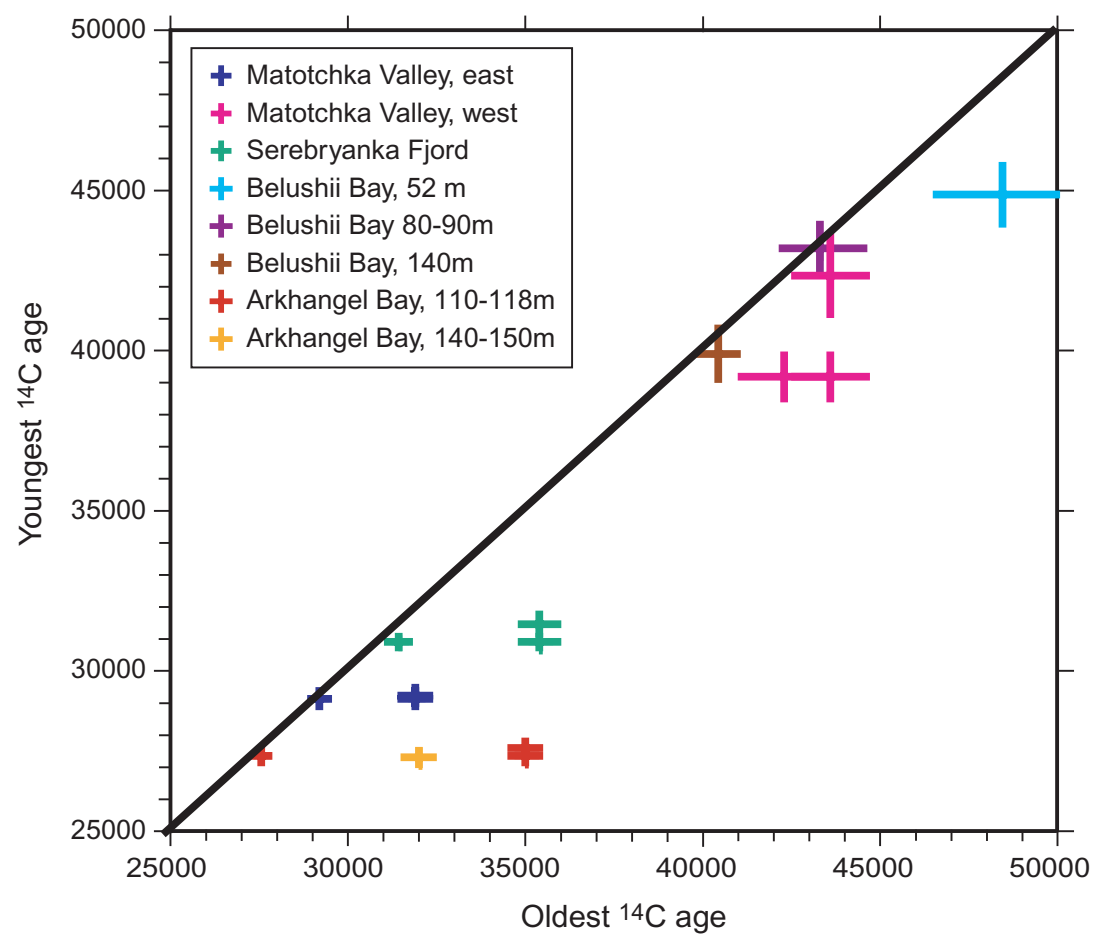

Fig. 4 Scatter plot of ${ }^{14} \mathrm{C}$ ages of different individuals (subsamples) from five of Grønlie's (1924) samples $( \pm 1 \sigma)$. The oldest age in each pair is plotted along the $x$ axis. Assuming that contamination by young ${ }^{14} \mathrm{C}$ results in an inaccurately young age, the vertical distance to the $1: 1$ line indicates the error. This does not preclude real age differences between subsamples, however.

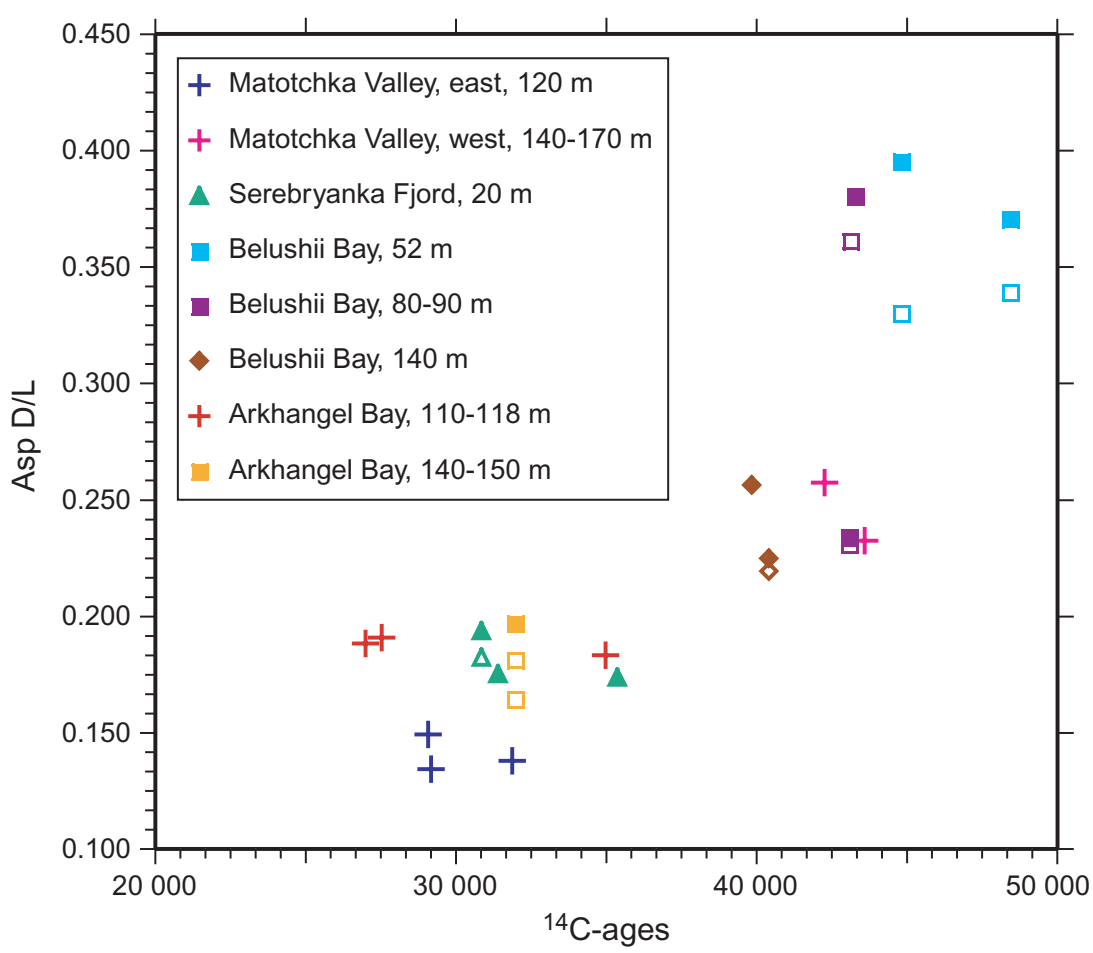

Fig. 5 Scatter plot of ${ }^{14} \mathrm{C}$ ages versus the extent of racemization (D/L) in the conventionally analysed total hydrolysable amino acid (THAA) population of aspartic acid (Asp) for Mya truncata. Crosses and filled symbols show the ${ }^{14} \mathrm{C}$ age and $D / L$ value from one specimen each. Open symbols show $\mathrm{D} / \mathrm{L}$ values for individuals (subsamples) from the same sample that have not been ${ }^{14} \mathrm{C}$ dated. For simplicity, errors are omitted. shells from Belushii Bay have ${ }^{14} \mathrm{C}$ ages of between 48 and $43 \mathrm{Ky}$, and D/L Asp values $>0.3$, which is considerably higher than that obtained from shells at other sites, and we therefore consider the corresponding ${ }^{14} \mathrm{C}$ ages as minimum ages. Some of the scatter in the correlation between ${ }^{14} \mathrm{C}$ age and D/L value (Fig. 5) can be explained by different temperature histories (north-south gradient, duration below sea level or glacial ice) between the localities. 
Fig. 6 The extent of racemization (D/L) in the total hydrolysable amino acid (THAA) population of aspartic acid (Asp) isolated from the intracrystalline fraction of the five pairs of subsampled shells with ${ }^{14} \mathrm{C}$ ages plotted in Fig. 4.

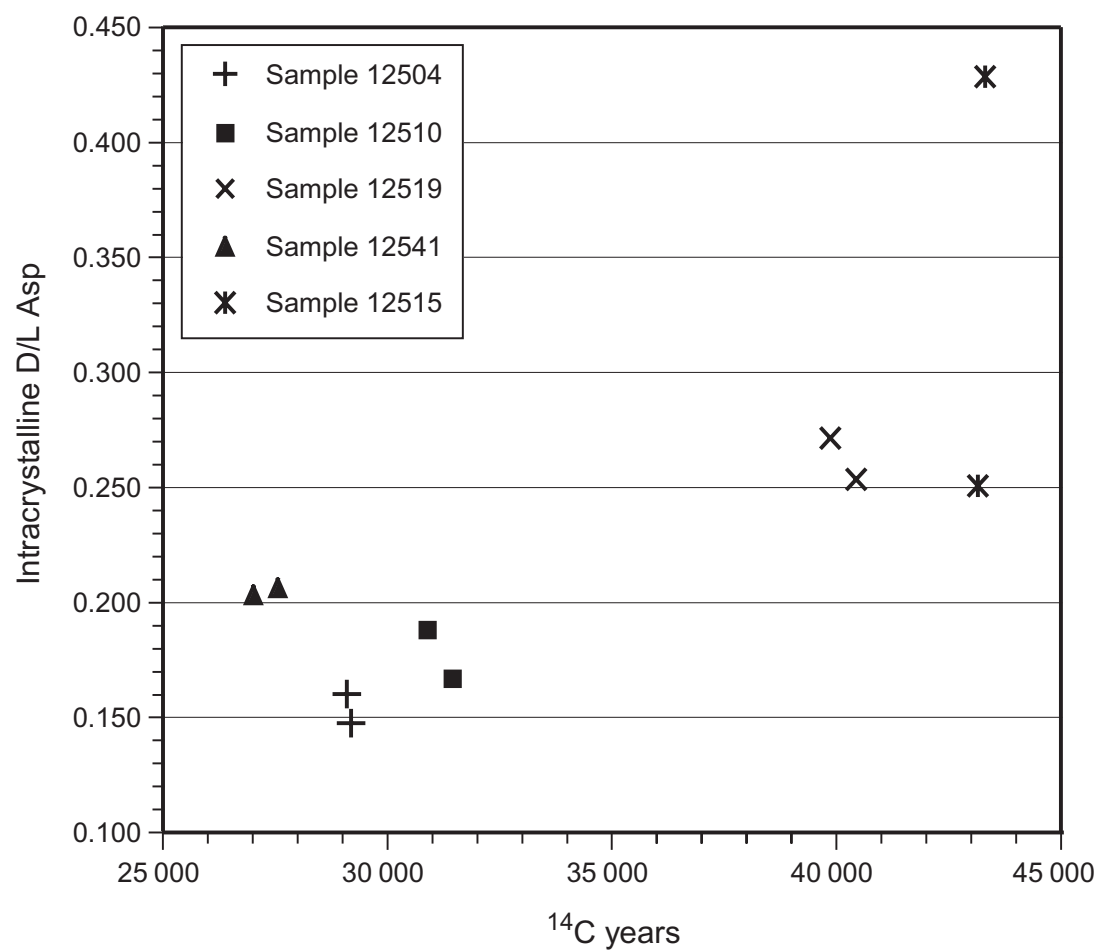

The five pairs of subsamples with almost identical ${ }^{14} \mathrm{C}$ ages (Fig. 4) were also analysed for their intra-THAA D/L values (Fig. 6); the results are supported by those based on other fractions (Table 2; Fig. 3). The D/L values are similar for four of the five replicate pairs, and for three of the pairs the $\mathrm{D} / \mathrm{L}$ values also increase with increasing ${ }^{14} \mathrm{C}$ age. These results strongly support the interpretation that the ${ }^{14} \mathrm{C}$ ages are reliable. For the pair (12541) with the youngest ${ }^{14} \mathrm{C}$ ages, however, the $\mathrm{D} / \mathrm{L}$ values are higher than expected. This may suggest that both subsamples have either been contaminated with young ${ }^{14} \mathrm{C}$, or experienced a period with a higher diagenetic temperature. For the oldest pair (12515), the high D/L value for one subsample indicates a non-finite ${ }^{14} \mathrm{C}$ age, and thus contamination of this subsample.

We conclude that several of the finite ${ }^{14} \mathrm{C}$ ages in the range of 35-27 Ky, and possibly even some of the older ones, are approximately correct, but we still suspect that contamination by young carbon has influenced the results to some degree. The oldest ages are most sensitive to contamination because the concentration of ${ }^{14} \mathrm{C}$ is about three times higher in a $27-\mathrm{Ky}$ shell than in a shell that is $17-\mathrm{Ky}$ older. In fact, the high $\mathrm{D} / \mathrm{L}$ values indicate that some of the ${ }^{14} \mathrm{C}$ ages in the range $48-43 \mathrm{Ky}$ should be considered as non-finite. Although it seems likely that some of the ${ }^{14} \mathrm{C}$ ages are trustworthy, we cannot identify individual samples that are unequivocally uncontaminated. This is partly because of the low resolution of $\mathrm{D} / \mathrm{L}$ values in a very cold climate, and an uncertain temperature history at the base of the overriding glaciers or below sea level.

\section{Have the molluscs been transported uphill by the ice sheet?}

If Novaya Zemlya was inundated by an ice sheet that was centred over the Barents Sea shelf during the LGM (Svendsen, Alexanderson et al. 2004), then some of the mollusc shells may have been transported uphill by glacier ice flowing eastwards and onto Novaya Zemlya. On the other hand, if a satellite ice dome was located over Novaya Zemlya during the LGM, as suggested by Zeeberg (2001), then any shell transport would have been downhill. From the north-west coast of the northern island, Forman et al. (1999) described in situ, sub-till mollusc shells up to about $35 \mathrm{~m}$ a.s.l. Unfortunately, from the descriptions in Grønlie (1924) it is impossible to identify in situ individuals. However, some shells are likely candidates, including for example the shells found at 80-140 m a.s.l. in the valley near the Belushii Bay (samples TSGF-12515-TSGF12519; Tables 1, 3). This valley is located on the eastern (lee) side of the island, where it seems unlikely that shells could have been transported uphill by a Barents-Kara ice sheet. Also, many of Grønlie's other samples were found in rugged and high topography, and often as a large concentration of shells, 


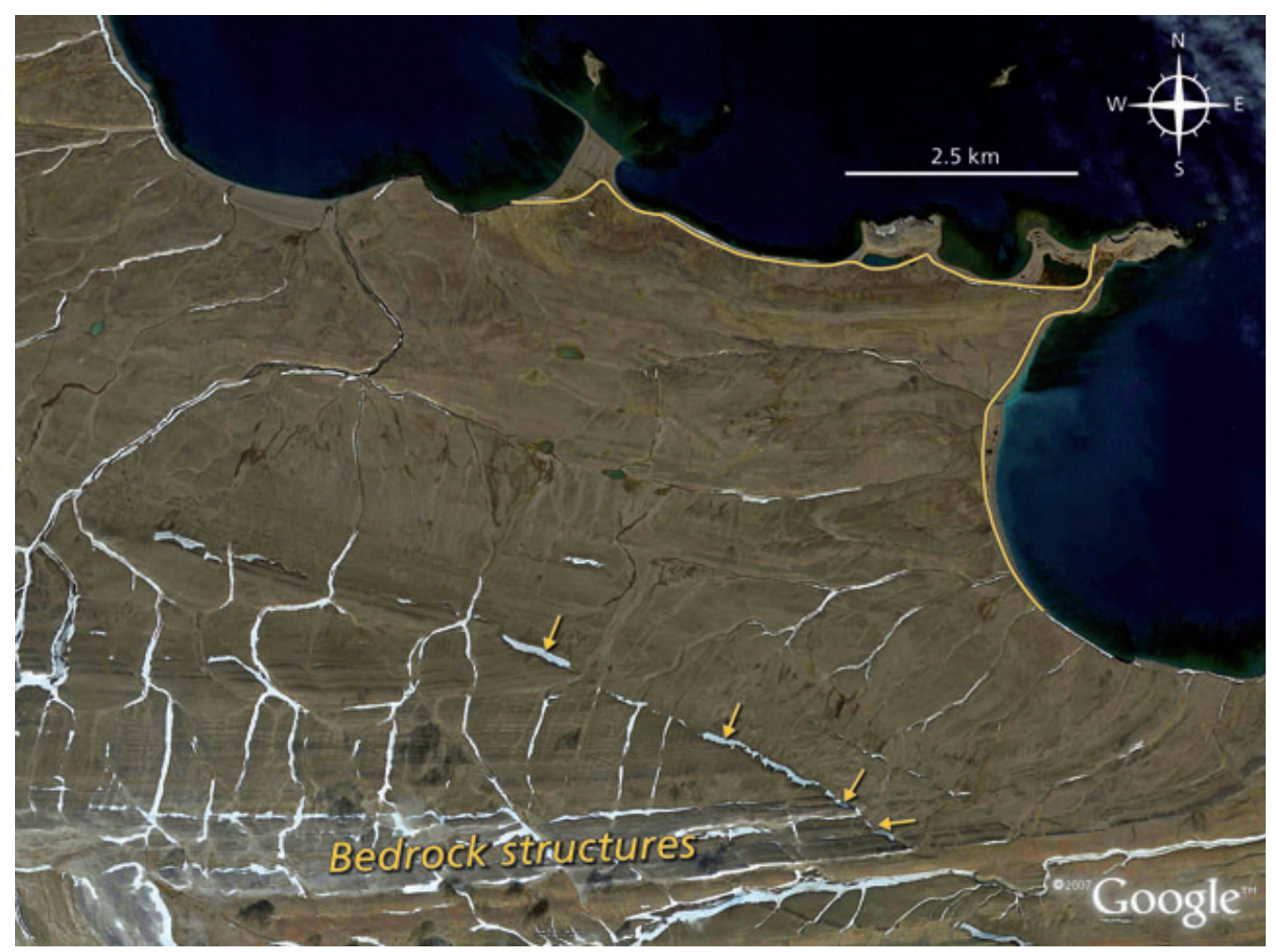

Fig. 7 Satellite image downloaded from Google Earth Professional on 15 November 2007 (image credit: Google Earth ${ }^{\text {tw }}$ mapping service). Arrows show a shoreline at about $140 \mathrm{~m}$ a.s.l. cutting bedrock structures. Above the shoreline the bedrock is completely exposed; below there is a thin cover of unconsolidated sediments. We interpret the latter as beach and shallow marine sediments subsequently modified by an ice sheet, and then by solifluction. Lower shorelines can be discerned in places. The thin yellow line shows the postglacial marine limit, about $10 \mathrm{~m}$ a.s.l., from Zeeberg et al. (2001).

including whole valves and thin shells. It is unlikely that all of these shells were transported significantly uphill by ice, although some probably were transported.

\section{Relative sea level}

Grønlie (1924) described shorelines up to 239 m a.s.l. Zeeberg (2001) has shown that some of these surfaces were confused with other features, whereas he accepts others. We also assume that some of the shorelines were correctly interpreted by Grønlie, except that we postulate that those above $20 \mathrm{~m}$ a.s.l. have been covered by glacial ice at some time. This assumption is supported by Forman et al. (1995), who described till-covered beaches on Novaya Zemlya up to ca. $100 \mathrm{~m}$ a.s.l. Near Cape Zhelaniya, at the north-east tip of the archipelago (Fig. 2), we interpret a distinct lineation on a satellite image as a shoreline that extends to an altitude of about $140 \mathrm{~m}$ a.s.l. (Fig. 7). The shoreline cuts bedrock structures, and marks the upper boundary of a thin sediment cover, which probably consists of shallow marine sediments that were overridden by an ice sheet, and then later modified by solifluction. In this region, Zeeberg et al. (2001) showed that the postglacial marine limit is only $10.5-13 \mathrm{~m}$ a.s.l., but they also found a pre-Holocene shoreline at $20-30 \mathrm{~m}$ a.s.l. near the coast. They report two ${ }^{14} \mathrm{C}$ ages of more than $40 \mathrm{Ky}$ from molluscs from a diamicton above the Holocene marine limit.

We conclude that raised pre-Holocene shorelines in Novaya Zemlya extend up to at least $140 \mathrm{~m}$ a.s.l., and perhaps significantly higher. Assuming that some of our shell ages are trustworthy implies that the corresponding shorelines were formed during MIS 3. Calibrating such old ages to a calendar-year scale is tenuous, but a ${ }^{14} \mathrm{C}$ age of about $30{ }^{14} \mathrm{C}$ Ky should correspond to about 36-33 cal Ky (van der Plicht et al. 2004; Fairbanks et al. 2005). MIS 3 shorelines considerably higher than Holocene shorelines are also known from other islands in the Barents and Kara seas, including Severnaya Zemlya (Möller et al. 2007), Vaigach (Zeeberg 2001) and Svalbard (Mangerud et al. 1992). Raised shorelines in areas that have been covered by ice sheets are normally interpreted to reflect glacioisostatic rebound after a deglaciation. And indeed, Forman et al. (1999) and Möller et al. (2007) presented sedimentological evidence that the raised MIS 3 beaches were formed during a fall in the relative sea level. This is 
Fig. 8 Site elevation versus ${ }^{14} \mathrm{C}$ age $( \pm 1 \sigma)$. For specimens that were dated twice, only the result from the Poznań Radiocarbon Laboratory, Poland, is plotted, but the ages from the Radiological Dating Laboratory, Norwegian University of Science and Technology, Trondheim, Norway, are nearly identical. Samples collected over an altitudinal range (Table 1) are plotted in the middle of the range. Because the southernmost and northernmost samples are separated by $360 \mathrm{~km}$, a considerable height difference between contemporaneous samples is expected as a result of glaci-isostatic tilting. However, samples younger than 30 Kya are found near both ends of the profile.

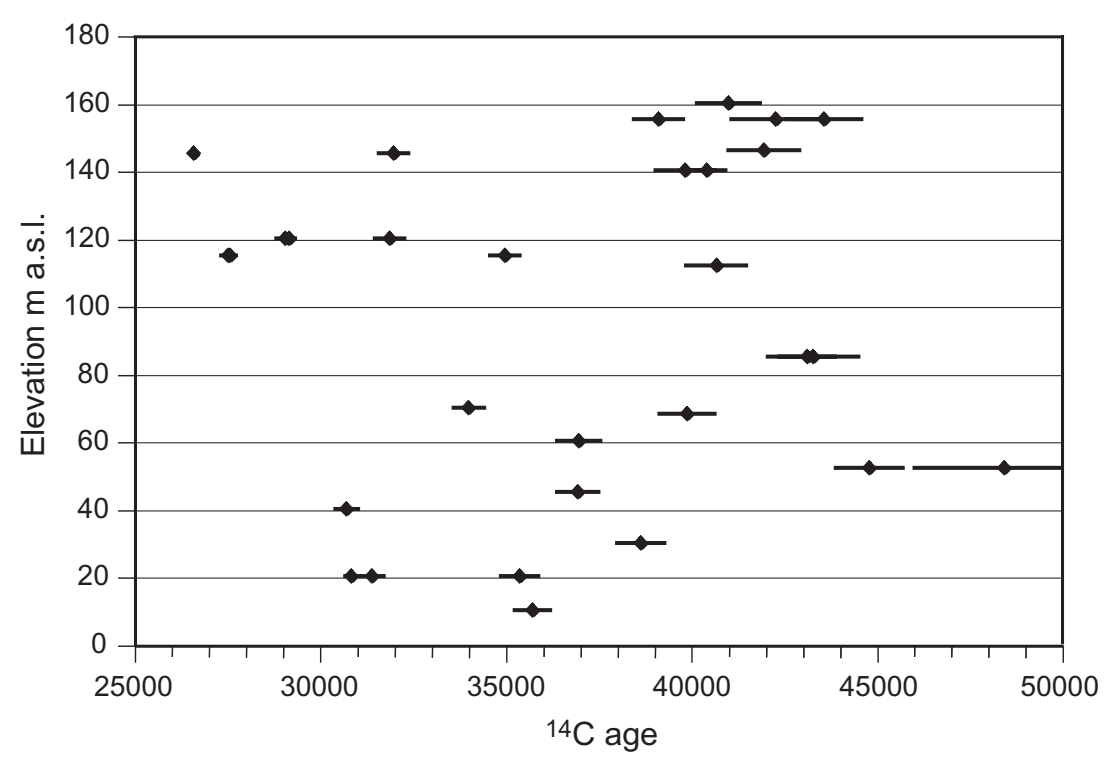

also supported by observations from the Pechora Sea to the south of Novaya Zemlya (Gataullin et al. 2001), where seismic profiles and sediment cores suggest that the Pechora delta was prograding during a period of MIS 3 when the relative sea level was falling. We would expect that the highest MIS 3 shorelines were formed during the deglaciation of some 50-40 Kya, and that they become progressively younger at lower elevations; however, this trend is not apparent in our dataset (Fig. 8). On the contrary, several of the youngest ages were obtained from molluscs collected at 120-140 m a.s.l. Taken at face value, our ages could be explained by a regression from ca. 160 to ca. $60 \mathrm{~m}$ a.s.l. between 40 and $35{ }^{14} \mathrm{C} \mathrm{Kya,} \mathrm{and} \mathrm{a} \mathrm{sub-}$ sequent sea-level rise up to $140 \mathrm{~m}$ a.s.l. However, if the sea level rose to such high levels as a result of glacioisostatic depression in front of the growing MIS 2 ice sheet, then we would also expect to find high shorelines from the subsequent deglaciation, which is not the case (Forman et al. 1999; Zeeberg et al. 2001). Although our dataset is not sufficient to reconstruct sea-level changes during MIS 3, we infer that the relative sea level on Novaya Zemlya was at least $160 \mathrm{~m}$ a.s.l. at some time during MIS 3. These high shore levels can only be explained by isostatic rebound after the preceding glaciation.

The postglacial (Holocene) marine limits in Novaya Zemlya are only 10-18 m a.s.l. (Forman et al. 1999; Zeeberg et al. 2001). This is much lower than the shorelines from the preceding ice-free period described above. Forman et al. (1999) obtained a minimum age for the last deglaciation of $9.2{ }^{14} \mathrm{C} \mathrm{Ky}$, whereas the marine limit was formed about $6{ }^{14} \mathrm{C}$ Kya. This suggests that the relative sea level was even below $10 \mathrm{~m}$ during the last deglaciation, and that the marine limit marks the culmination of a subsequent transgression. The simplest interpretation is that the LGM ice sheet was very thin across Novaya Zemlya. Serebryanny \& Malyasova (1998) and Serebryanny et al. (1998) reported two radiocarbon dates yielding 15.3 and $15.1{ }^{14} \mathrm{C} \mathrm{Ky}$ (about $18-19 \mathrm{cal} \mathrm{Ky}$ ) from Novaya Zemlya. We are somewhat sceptical about the reliability of these ages because bulk sediments with low organic content were dated, and also because such old ages are in conflict with deglaciation dates from the surrounding shelf area (Svendsen, Gataullin et al. 2004). However, we are open to the possibility that they are approximately correct, and thus that Novaya Zemlya was deglaciated prior to about $18 \mathrm{cal} \mathrm{Kya.} \mathrm{This} \mathrm{would} \mathrm{also}$ make it easier to understand the low relative sea level during the deglaciation, because the global (eustatic) sea level at $18 \mathrm{cal}$ Kya was almost $100 \mathrm{~m}$ lower than at the start of the Holocene (Peltier \& Fairbanks 2006).

\section{The palaeoenvironment during MIS 3}

Samples with sub-Arctic species include individual specimens with ${ }^{14} \mathrm{C}$ ages that span the range of obtained ages, as do samples with only Arctic species. If the ${ }^{14} \mathrm{C}$ ages of samples younger than $35 \mathrm{Ky}$ are nearly correct, then subArctic species, including $C$. islandica, lived along the coast of Novaya Zemlya during MIS 3. A similar fauna is also known from deposits of the corresponding Kapp Ekholm interstadial in Svalbard (Mangerud \& Svendsen 1992). The diversity is highest in samples including sub-Arctic species, as would be expected if the samples were representative of the original fauna. 


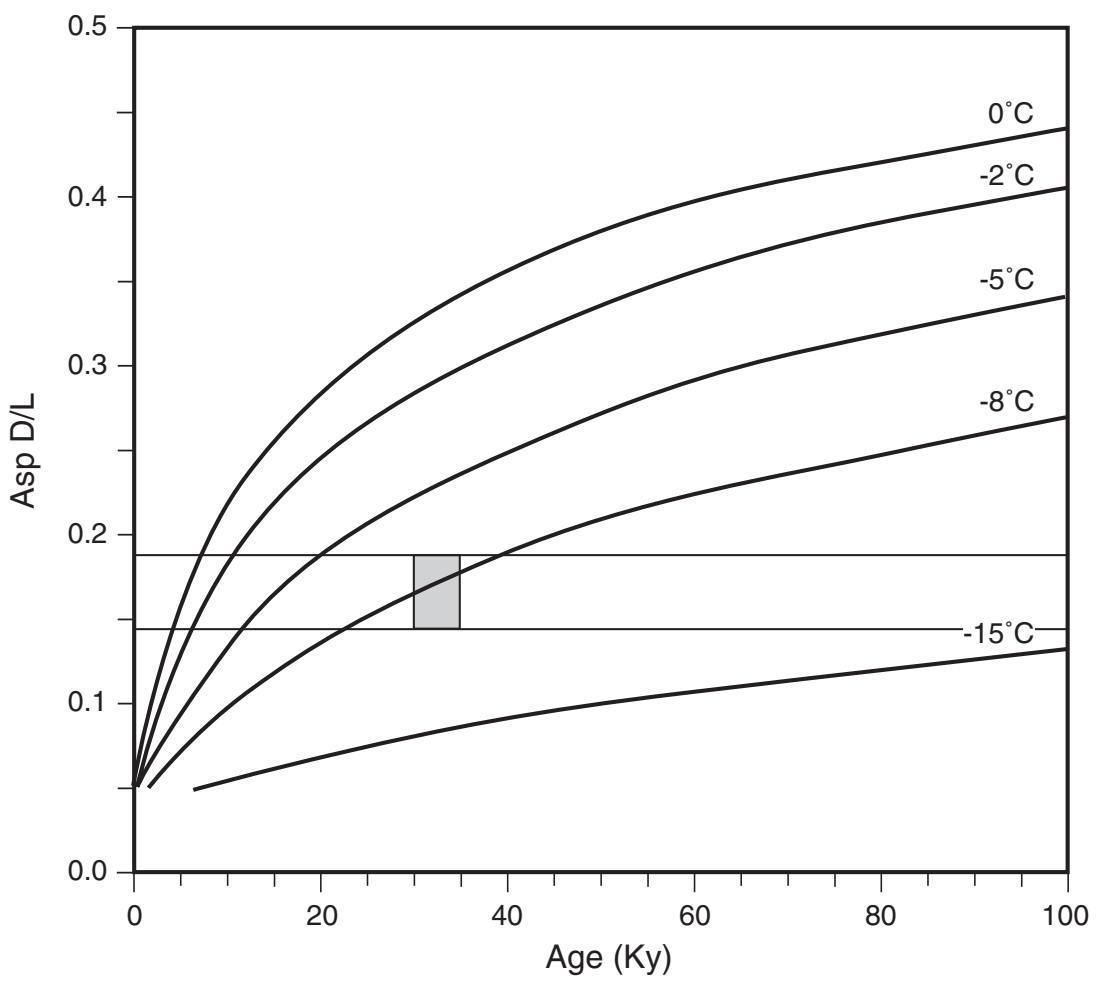

Fig. 9 Kinetic model of Manley et al. (2000) solved for the extent of aspartic acid racemization (THAA Asp D/L) for five different effective diagenetic temperatures $\left(T_{\text {eff }}\right)$. The models illustrate the expected increase in D/L values in Mya truncata under isothermal conditions. Living molluscs have D/L values of about 0.04 , and below $-15^{\circ} \mathrm{C}$ the rate of racemization is extremely low. Horizontal lines show the $\pm 2 \sigma$ range of the mean $D / L$ value of the eight specimens with reliable ages ranging from ca. 30 to ca. 35 cal years Kya. The box marks the mentioned age interval; the corresponding $T_{\text {eff }}$ ranges from $-7.7^{\circ} \mathrm{C}$ to $-8.5^{\circ} \mathrm{C}$.

\section{The glaciation history of Novaya Zemlya during MIS 4-MIS 2}

It is generally agreed that there was a large Barents-Kara ice sheet during MIS 4 and early MIS 3, and that this was the last time the ice sheet reached mainland Russia south of the Barents-Kara seas (Svendsen, Alexanderson et al. 2004; Larsen et al. 2006; Möller et al. 2007). The timing of the deglaciation from mainland Russia is not well constrained, but a number of OSL ages below the youngest till are about $60 \mathrm{Ky}$ (Kjær et al. 2003; Kjær et al. 2006; Henriksen et al. 2008), indicating a deglaciation well after this time. Polyak et al. (2000) obtained minimum ages, believed to be close to deglaciation ages, of $38-37{ }^{14} \mathrm{C} \mathrm{Ky}$ from marine cores in the Pechora Sea. These are reasonably consistent with the ages from Novaya Zemlya. A similar glaciation history is described from Svalbard (Mangerud et al. 1998) and Zevernaya Zemlya (Möller et al. 2007). Zeeberg (2001) constructed a glaciation curve leaving Novaya Zemlya ice-free from 40-30 Kya. Our larger data set supports this conclusion, although it is difficult to determine the exact age for the onset of the ice-free period. Theoretically, the oldest reliable finite ages from Novaya Zemlya represent the age for the deglaciation of the islands. Although we consider the oldest ${ }^{14} \mathrm{C}$ ages as minimum-limiting ages, the analyses indicate that the deglaciation of Novaya Zemlya did not occur later than about $35 \mathrm{cal}$ Kya.
The extent of amino acid racemization depends on both the age and the effective diagenetic temperature $\left(T_{\text {eff }}\right)$ since the death of the mollusc. The temperature sensitivity of Asp racemization in $M$. truncata has been determined based on laboratory controlled heating experiments, combined with the analysis of shells of known age (Manley et al. 2000) (Fig. 9). On the basis of these kinetic models, we can assess the temperature history of the Novaya Zemlya shells, assuming that the ${ }^{14} \mathrm{C}$ ages are correct (but most calculations are valid even if the ${ }^{14} \mathrm{C}$ ages are non-finite). We use the eight specimens with ${ }^{14} \mathrm{C}$ ages of $32-27 \mathrm{Ky}$, which we believe are the most reliable results. The mean Asp D/L value of these eight shells is $0.171 \pm 0.026$, and the approximate mean age is probably between 35 and $30 \mathrm{cal} \mathrm{Ky}$. Solving the kinetic model of Manley et al. (2000) yields a $T_{\text {eff }}$ between $-7.7^{\circ} \mathrm{C}$ and $-8.5^{\circ} \mathrm{C}$ for ages ranging from 35 to $30 \mathrm{Ky}$. The $T_{\text {eff }}$ integrates the effects of multiple thermal conditions, which can be represented by three intervals: (1) a "hightemperature" interval, when the shells were below sea level or glacier ice, (2) one or more low-temperature intervals, when the shells were exposed subaerially during glacial climate, and (3) an interval of intermediate temperature during the Holocene (11-Ky duration), when shells were exposed to subaerial conditions similar to modern conditions, i.e. from $-6^{\circ} \mathrm{C}$ to $-8^{\circ} \mathrm{C}$. To satisfy an overall $T_{\text {eff }}$ of between $-7.7^{\circ} \mathrm{C}$ and $-8.5^{\circ} \mathrm{C}$ for the $35-30-K y$ post-depositional history, while accounting for 
Fig. 10 Relationship between the duration of the "warm" interval (ice or marine cover) and the effective diagenetic temperature ( $\left.T_{\text {eff }}\right)$ of the remaining cold subaerial interval necessary to balance an overall $T_{\text {eff }}$ of between $-7.7^{\circ} \mathrm{C}$ and $-8.5^{\circ} \mathrm{C}$ for Mya shells, the ages of which range from 30 to $35 \mathrm{cal} \mathrm{Kya.} \mathrm{The} \mathrm{widths} \mathrm{of} \mathrm{the}$ temperature/duration bands delimit the range of solutions based on these $T_{\text {eff }}$ and age ranges. As the duration of the warm interval increases, the $T_{\text {eff }}$ of the remaining interval must decrease exponentially, as seen in Fig. 9. The solution also assumes that the shells experienced an interval of temperatures similar to that of modern times (from $-6^{\circ} \mathrm{C}$ to $-8^{\circ} \mathrm{C}$ ) that lasted for the entire Holocene (11 cal Ky).

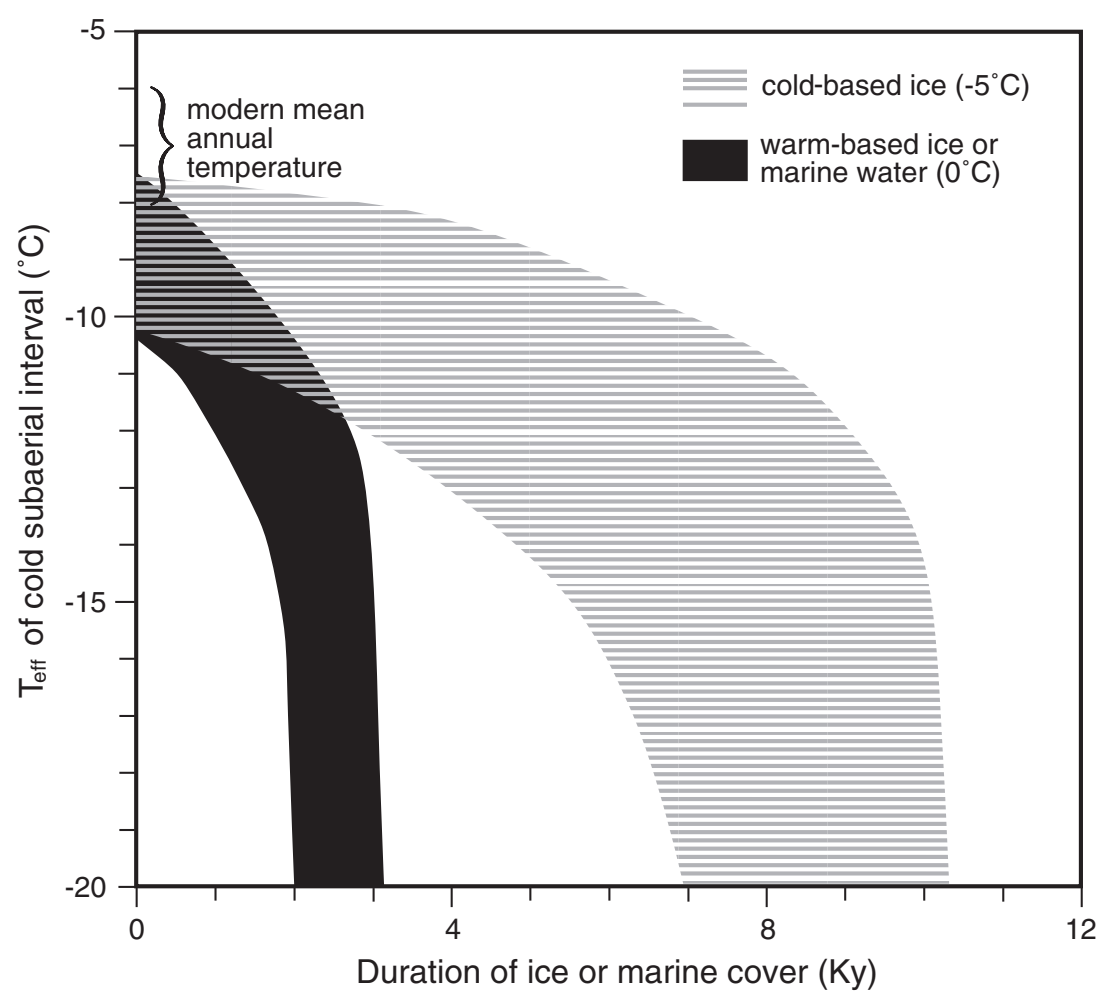

a period of 11000 years when temperatures were between $-6^{\circ} \mathrm{C}$ and $-8^{\circ} \mathrm{C}$, and assuming that the kinetic equations are correct, the shells could not withstand more than about $3 \mathrm{Ky}$ of marine or ice cover at $0^{\circ} \mathrm{C}$, even if the $T_{\text {eff }}$ of the remaining time (i.e., the cold interval 2) was below $-15^{\circ} \mathrm{C}$ (Fig. 10), when hardly any racemization would occur (Fig. 9). If the ice was cold-based, however, the shells could have spent up to $10 \mathrm{Ky}$ of their post-depositional history below ice at $-5^{\circ} \mathrm{C}$. Under the assumption that Novaya Zemlya was deglaciated shortly after the Younger Dryas (Svendsen, Gataullin et al. 2004), this may suggest that the islands became ice-covered during the later part of the Late Weichselian, possibly well after the LGM. On the other hand, if Novaya Zemlya was deglaciated at $18 \mathrm{cal} \mathrm{Kya,} \mathrm{as} \mathrm{discussed} \mathrm{above} \mathrm{(Serebry-}$ anny et al. 1998; Serebryanny \& Malyasova 1998), then the glaciation could have started earlier.

Assuming that the ${ }^{14} \mathrm{C}$ ages of the shells are minimum ages, then the short duration of ice or marine cover calculated based on the $\mathrm{D} / \mathrm{L}$ values represents a maximum duration. This means that the molluscs with the lowest D/L values could not have been ice-covered during two glaciations, especially because the earlier MIS 4-early MIS 3 glaciation was probably of longer duration. Therefore, the low $\mathrm{D} / \mathrm{L}$ values indicate that most of the studied molluscs are of MIS 3 age, a conclusion drawn independently of the ${ }^{14} \mathrm{C}$ ages. The short duration of ice cover indicated by the $\mathrm{D} / \mathrm{L}$ values is also consistent with modest ice loading, as indicated by the low Holocene marine limits (about $18 \mathrm{~m}$ a.s.l.; Forman et al. 1999; Zeeberg et al. 2001).

The timing and location of ice-sheet inception during MIS 3/2 in the Barents-Kara Sea region is not well known. An obvious thought is that glaciers in Novaya Zemlya and the other islands might have served as the nuclei for ice-sheet growth, similar to that described for older glaciations in Severnaya Zemlya (Möller et al. 2007). If so, then our results suggest that ice over Novaya Zemlya remained thin and cold during MIS 2. However, the local glaciers in Severnaya Zemlya (Möller et al. 2007) and the northernmost tip of the Ural Mountains (Mangerud et al. 2008) hardly expanded during the LGM, and therefore, perhaps, neither did glaciers in Novaya Zemlya, which is located between these two areas. An alternative hypothesis is therefore that precipitation from the Atlantic during the inception period was restricted to the western Barents Sea, and that the ice sheet started to grow in Svalbard and the western Barents Sea, and subsequently overran Novaya Zemlya.

Global ice volume at 30 Kya was $60-65 \%$ of the LGM volume (Lambeck \& Chappell 2001; Peltier \& Fairbanks 2006). This contrasts with our results that indicate the Barents-Kara ice sheet did not exist $30 \mathrm{Kya}$, indicating that the Barents-Kara ice sheet responded faster and with 
a larger amplitude to global climate (and sea-level) changes than other ice sheets.

\section{Conclusions}

We obtained $33{ }^{14} \mathrm{C}$ ages in the range of $48-26{ }^{14} \mathrm{C} \mathrm{Ky}$ on mollusc samples from Novaya Zemlya. Amino acid D/L values indicate that many of the finite ${ }^{14} \mathrm{C}$ ages are reliable, whereas some are minimum ages only.

During the later part of MIS $3\left(35-27{ }^{14} \mathrm{C}\right.$ Kya), Novaya Zemlya did not support glaciers larger than those present today. This implies that the Barents-Kara ice sheet did not exist at this time, whereas global ice volume at the same time was $60-65 \%$ of the LGM volume.

The low D/L values in most shells indicate that they have not been subjected to the relatively high temperatures under glacier ice or marine water $\left(0^{\circ} \mathrm{C}\right)$ for longer than about $3 \mathrm{Ky}$. Under cold-based ice of $-5^{\circ} \mathrm{C}$, the duration of glacier cover in Novaya Zemlya during the LGM may have been up to $10 \mathrm{Ky}$.

These results from Novaya Zemlya are consistent with reconstructions of the ice-sheet history from northern Russia and Svalbard. The limited extent and duration of ice cover is also consistent with the low Holocene marine limit below $18 \mathrm{~m}$ a.s.l.

If some of the ${ }^{14} \mathrm{C}$ ages around $30 \mathrm{Ky}$ are correct, as we concluded, then sub-Arctic mollusc faunas immigrated to the eastern Barents Sea during MIS 3.

We obtained Holocene ${ }^{14} \mathrm{C}$ ages on a few marine molluscs. One shows that at least one glacier was smaller about 4000 years ago than in 1921, and the other shows that M. edulis was present in the area about 4700 years ago.

\section{Acknowledgements}

This is a contribution to The Ice Age Development and Human Settlement in Northern Eurasia (ICEHUS) project, funded by grants from the Research Council of Norway. JH thanks his $\mathrm{PhD}$ supervisor Dr Elsebeth Thomsen for suggesting his participation in this study as obligatory work in connection with his doctoral study at the Tromsø University Museum. The amino acid analyses were performed by J. Bright and C. Orem with support from the US National Science Foundation grant EAR0620455. We express our thanks to J. Zeeberg and an anonymous reviewer for constructive comments on the manuscript. This is publication no. 189 from the Bjerknes Centre for Climate Research.

\section{References}

Bondevik S., Mangerud J., Ronnert L. \& Salvigsen O. 1995. Postglacial sea-level history of Edgeøya and Barentsøya, eastern Svalbard. Polar Research 14, 153-180.
Fairbanks R.G., Mortlock R.A., Chiu T.-C., Cao L., Kaplan A., Guilderson T.P., Fairbanks T.W., Bloom A.L., Grootes P.M. \& Nadeau M.-J. 2005. Radiocarbon calibration curve spanning 0 to 50,000 years BP based on paired ${ }^{230} \mathrm{Th} /{ }^{234} \mathrm{U} /$ $238 \mathrm{U}$ and ${ }^{14} \mathrm{C}$ dates on pristine corals. Quaternary Science Reviews 24, 1781-1796.

Forman S., Lubinski D., Miller G.H., Snyder J., Matishov G., Korsun S. \& Myslivets V. 1995. Postglacial emergence and distribution of late Weichselian ice-sheet loads in the northern Barents and Kara seas, Russia. Geology 23, 113-116.

Forman S.L., Lubinski D.J., Zeeberg J.J., Polyak L., Miller G.H., Matishov G. \& Tarasov G. 1999. Postglacial emergence and Late Quaternary glaciation on northern Novaya Zemlya, Arctic Russia. Boreas 28, 133-145.

Forman S.L. \& Polyak L. 1997. Radiocarbon content of pre-bomb marine mollusks and variations in the ${ }^{14} \mathrm{C}$ reservoir age for coastal areas of the Barents and Kara seas, Russia. Geophysical Research Letters 24, 885-888.

Funder S., Demidov I. \& Yelovicheva Y. 2002. Hydrography and mollusc faunas of the Baltic and the White Sea-North Sea seaway in the Eemian. Palaeogeography, Palaeoclimatology, Palaeoecology 184, 275-304.

Galkin Y.I. 1998. Long-term changes in the distribution of molluscs in the Barents Sea related to climate. Berichte zur Polarforschung 287, 100-143.

Gataullin V., Mangerud J. \& Svendsen J.I. 2001. The extent of the Late Weichselian ice sheet in the southeastern Barents Sea. Global and Planetary Change 31, 451-472.

Goodfriend G. A., Brigham-Grette J. \& Miller G.H. 1996. Enhanced age resolution of the marine Quaternary record in the arctic using aspartic acid racemization dating of bivalve shells. Quarternary Research 45, 176-187.

Grønlie O.T. 1924. Contributions to the Quaternary geology of Novaya Zemlya. Vol. 21. Report of the scientific results of the Norwegian expedition to Novaya Zemlya 1921. Kristiania (Oslo): Videnskapsselskapet i Kristiania.

Henriksen M., Mangerud J., Matiouchkov A., Murray A., Paus A. \& Svendsen J.I. 2008. Intriguing climatic shifts in a 90 kyr old lake record from northern Russia. Boreas 37, 20-37.

Hjort C., Mangerud J., Adrielsson L., Bondevik S., Landvik J.Y. \& Salvigsen O. 1995. Radiocarbon dated common mussels Mytilus edulis from eastern Svalbard and the Holocene marine climatic optimum. Polar Research 14, 239-243.

Holtedahl O. 1922. Brief account of the expedition. Vol. 1. Report of the scientific results of the Norwegian expedition to Novaya Zemlya 1921. Kristiania (Oslo): Videnskapsselskapet i Kristiania.

Hughen K., Baillie M., Bard E., Beck J.W., Bertrand C., Blackwell P., Buck C., Burr G., Cutler K., Damon P., Edwards R., Fairbanks R., Friedrich M., Guilderson T., Kromer B., McCormac G., Manning S., Ramsey C., Reimer P., Reimer R., Remmele S., Southon J., Stuiver M., Talamo S., Taylor F., van Der Plicht J. \& Weyhenmeyer C. 
2004. Marine04 marine radiocarbon age calibration, 0-26 cal Kyr BP. Radiocarbon 46, 1059-1086.

Kaufman D.S. \& Manley W.F. 1998. A new procedure for determining DL amino acid ratios in fossils using reverse phase liquid chromatography. Quaternary Science Reviews 17, 987-1000.

Kjær K.H., Demidov I.N., Larsen E., Murray A. \& Nielsen J.K. 2003. Mezen Bay-a key area for understanding Weichselian glaciations in northern Russia. Journal of Quaternary Science 18, 73-93.

Kjær K., Larsen E., Funder S., Demidov I., Jensen M., Håkansson L. \& Murray A. 2006. Eurasian ice-sheet interaction in northwestern Russia throughout the late Quaternary. Boreas 35, 444-475.

Lambeck K. \& Chappell J. 2001. Sea level change through the last glacial cycle. Science 292, 679-686.

Larsen E., Kjær K.H., Demidov I.N., Funder S., Grosfjeld K., Houmark-Nielsen M., Jensen M., Linge H. \& Lysa A. 2006. Late Pleistocene glacial and lake history of northwestern Russia. Boreas 35, 394-424.

Mangerud J., Bolstad M., Elgersma A., Helliksen D., Landvik J.Y., Lønne I., Lycke A.K., Salvigsen O., Sandahl T. \& Svendsen J.I. 1992. The last glacial maximum on Spitsbergen, Svalbard. Quaternary Research $38,1-31$.

Mangerud J., Bondevik S., Gulliksen S., Hufthammer A. \& Høisæter T. 2006. Marine ${ }^{14} \mathrm{C}$ reservoir ages for 19th century whales and molluscs from the North Atlantic. Quaternary Science Reviews 25, 3228-3245.

Mangerud J., Dokken T., Hebbeln D., Heggen B., Ingólfsson O., Landvik J.Y., Mejdahl V., Svendsen J.I. \& Vorren T.O. 1998. Fluctuations of the Svalbard-Barents Sea Ice Sheet during the last 150000 years. Quaternary Science Reviews 17, $11-42$.

Mangerud J., Gosse J., Matiouchkov A. \& Dolvik T. 2008. Glaciers in the Polar Urals, Russia, were not much larger during the Last Global Glacial Maximum than today. Quaternary Science Reviews 27, 1047-1057.

Mangerud J. \& Gulliksen S. 1975. Apparent radiocarbon ages of recent marine shells from Norway, Spitsbergen, and Arctic Canada. Quaternary Research 5, 263-273.

Mangerud J. \& Svendsen J.I. 1992. The last interglacial-glacial period on Spitsbergen, Svalbard. Quaternary Science Reviews 11, 633-664.

Manley W.F., Miller G.H. \& Czywczynski J. 2000. Kinetics of aspartic acid racemization in Mya and Hiatella: modelling age and paleotemperature of high-latitude Quaternary mollusks. In G.A. Goodfriend et al. (eds.): Perspectives in amino acid and protein geochemistry. Pp. 202-218. New York: Oxford University Press.

Möller P., Lubinski D.J., Ingolfsson O., Forman S.L., Seidenkrantz M.-S., Bolshiyanov D.Y., Lokrantz H., Antonov O., Pavlov M., Ljung K., Zeeberg J.J. \& Andreev A. 2007. Erratum to: Severnaya Zemlya, Arctic Russia: a nucleation area for Kara Sea ice sheets during the Middle to Late Quaternary. Quaternary Science Reviews 26, 1149-1191.
Peltier W. \& Fairbanks R. 2006. Global glacial ice volume and Last Glacial Maximum duration from an extended Barbados sea level record. Quaternary Science Reviews 25, 3322-3337.

Penkman K., Kaufman D.S., Maddy D. \& Collins M. 2008. Closed-system behavior of the intra-crystalline fraction of amino acids in mollusk shells. Quaternary Geochronology 3, $2-25$.

Polyak L., Gataullin V., Okuneva O. \& Stelle V. 2000. New constraints on the limits of the Barents-Kara ice sheet during the Last Glacial Maximum based on borehole stratigraphy from the Pechora Sea. Geology 28, 611-614.

Reimer P., Baillie M., Bard E., Bayliss A., Beck J.W., Bertrand C., Blackwell P., Buck C., Burr G., Cutler K., Damon P., Edwards R., Fairbanks R., Friedrich M., Guilderson T., Hogg A., Hughen K., Kromer B., McCormac G., Manning S., Ramsey C.B., Reimer R., Remmele S., Southon J., Stuiver M., Talamo S., Taylor F., van Der Plicht J. \& Weyhenmeyer C. 2004. IntCal04 terrestrial radiocarbon age calibration, 0-26 cal Kyr BP. Radiocarbon 46, 1029-1058.

Salvigsen O., Forman S.L. \& Miller G.H. 1992. Thermophilous molluscs on Svalbard during the Holocene and their paleoclimatic implications. Polar Research 11, 1-10.

Serebryanny L., Andreev A., Malyasova E., Tarasov P. \& Romanenko F. 1998. Lateglacial and early-Holocene environments of Novaya Zemlya and the Kara Sea region of the Russian Arctic. The Holocene 8, 323-330.

Serebryanny L. \& Malyasova E. 1998. The Quaternary vegetation and landscape evolution of Novaya Zemlya in the light of palynological records. Quaternary International 45/46, 59-70.

Svendsen J.I., Alexanderson H., Astakhov V.I., Demidov I., Dowdeswell J.A., Funder S., Gataullin V., Henriksen M., Hjort C., Houmark-Nielsen M., Hubberten H.W., Ingólfson O., Jakobsson M., Kjær K., Larsen E., Lokrantz H., Lunkka J.P., Lyså A., Mangerud J., Matiouchkov A., Murray A., Möller P., Niessen F., Nikolskaya O., Polyak P., Saarnisto M., Siegert C., Siegert M., Spielhagen R. \& Stein R. 2004. Late Quaternary ice sheet history of Northern Eurasia. Quaternary Science Reviews 23, 1229-1271.

Svendsen J.I., Gataullin V., Mangerud J. \& Polyak L. 2004. The glacial history of the Barents and Kara sea region. In J. Ehlers \& P.L. Gibbard (eds.): Quaternary glaciations-extent and chronology. Part I. Europe. Pp. 369-378. Amsterdam: Elsevier.

Svendsen J.I. \& Mangerud J. 1997. Holocene glacial and climatic variations on Spitsbergen, Svalbard. The Holocene 7, 45-57.

van der Plicht J., Beck J., Bard E., Baillie M., Blackwell P., Buck C., Friedrich M., Guilderson T., Hughen K., Kromer B., McCormac F., Ramsey C.B., Reimer P., Reimer R., Remmele S., Richards D., Southon J., Stuiver M. \& Weyhenmeyer C. 2004. NotCal04-comparison/calibration 14C records 26-50 cal Kyr BP. Radiocarbon 46, 1225-1238.

Wehmiller J. \& Miller G. 2000. Aminostratigraphic dating methods in Quaternary geology. In J.S. Noller et al. (eds.): 
Quaternary geochronology: methods and applications. Pp.

187-222. Washington, DC: American Geophysical Union. Zeeberg J.J. 2001. Climate and glacial history of the Novaya Zemlya Archipelago, Russian Arctic with notes on the region's history and exploration. Amsterdam: Rozenbarg Publishers. Zeeberg J.J., Forman S.L. \& Polyak L. 2003. Glacier extent in a Novaya Zemlya fjord during the "Little Ice Age" inferred from glaciomarine sediment records. Polar Research 22, 385-394.

Zeeberg J.J., Lubinski D.J. \& Forman S.L. 2001. Holocene relative sea-level history of Novaya Zemlya, Russia, and implications for Late Weichselian ice-sheet loading. Quarternary Research 56, 218-230. 